\title{
ICHTML 2020 - How learning technology wins coronavirus
}

\author{
Vita Hamaniuk, Serhiy Semerikov*, and Yaroslav Shramko \\ Kryvyi Rih State Pedagogical University, 54 Gagarina Ave., Kryvyi Rih, 50086, Ukraine
}

\begin{abstract}
This is an introductory text to a collection of papers from the ICHTML 2020: The International Conference on History, Theory and Methodology of Learning, which held in Kryvyi Rih State Pedagogical University, Kryvyi Rih, Ukraine, on the May 13-15, 2020. It consists of short introduction, conference review and some observations about the event and its future.
\end{abstract}

\section{Introduction: from social distancing to distant learning}

The rapid spread of the coronavirus that causes COVID19 has sparked worldwide alarm and media hype [1]. In the Ukraine, the Ministry of Healthcare is advising people to be prepared for disruptions to daily life that will be necessary if the coronavirus spreads within communities. On March 11, 2020 the Cabinet of Ministers of Ukraine introduced a three-week nationwide quarantine in connection with a pandemic, and all public events in the country have been canceled: "In accordance with the article 29 of the Law of Ukraine On Protection of the population from the infectious diseases to prevent the spread in the territory of Ukraine of coronavirus Covid-19 and considering the decision of the State Commission on technogeneous and ecological security and emergency dated March 10, 2020, the Cabinet of Ministers ordered to initiate the quarantine from March 12 until April 3, 2020" [2].

In 1665, following an outbreak of the bubonic plague in England, Cambridge University closed its doors, forcing Isaak Newton to return home to Woolsthorpe Manor. It was a version of "social distancing" of $17^{\text {th }}$ century, a public health tool making a comeback this year as school and universities, including Kryvyi Rih State Pedagogical University, send people home to try to slow the spread of the novel coronavirus.

Without his professors to guide him, Newton apparently thrived: the papers he wrote on mathematical problems he had begun at Cambridge became early calculus; the experiments with a prisms in his bedroom give us the theories on optics; and even apple tree inspired the gravity laws: "In the year he retired again from Cambridge on account of the plague to his mother in Lincolnshire \& whilst he was musing in a garden it came into his thought that the same power of gravity (which made an apple fall from the tree to the ground) was not limited to a certain distance from the earth but must extend much farther than was usually thought - Why not as high as the Moon said he to himself" [3].
"Newton returned to Cambridge in 1667 , theories in hand. Within six months, he was made a fellow; two years later, a professor. So if you're working or studying from home over the next few weeks, perhaps remember the example Newton set", wrote Gillian Brockell for The Washington Post's history blog [4].

These risk-control decisions [2] have temporary led millions of students in Ukraine and other countries into massive open distance learning using contemporary educational technologies (Fig. 1):

1. To help minimize the impact of the coronavirus outbreak on students, the Coursera community is launching Coursera Coronavirus Response Initiative, a global effort to assist universities and colleges to deliver courseware online [5]. Educational institutions may enroll students in 3800 courses and 400 specializations through July 31, 2020 free of charge.

2. University of Massachusetts Amherst plans to shift their instruction to an online modality and help students to continue making progress in their studies with disruption-resilient instruction [6]. Instructors are asked to follow next steps:

- use the Learning Management Systems (LMS) of Moodle and Blackboard for communicating with students about your course;

- use the LMS to share course content, such as lecture notes, PowerPoint slides, assignments, and other course materials that can be uploaded to LMS course site;

- use Zoom to stream or record class lectures: faculty members may choose to schedule a Zoom class meeting with their students during their normally scheduled course day/time (these Zoom class lectures can also be recorded to be viewed at a later time if desired);

- adapt the course content, pedagogy, and assessment, if necessary, to fit this new modality of instruction.

The base of learning technologies is learning sciences, an interdisciplinary field that works to critical theoretical understanding of cognition and learning as well as design and implementation of learning innovations, and the improvement of learning/instructional methodologies.

\footnotetext{
* Corresponding author: semerikov@gmail.com
} 


\section{< Note@75 勻 : \\ chris \\ $3 / 9 / 20$ \\ 30}

\section{Online Discussions and Office Hours}

Hi all,

as you probably already anticipated, I will move my discussion sections and office hours online, starting tomorrow. I'm sure your biggest concern right now is how we can continue to have class. Don't worry - I am prepared:

- The default method we'll use is Zoom - you'll have to download the client at https:-/zoom.us. I will post the data you need to join the meeting on bcourses.

- In case Zoom doesn't work for some reason (e.g. because the service is overloaded), we will use Google Meet. If that happens, III announce it beforehand. If you don't use an @berkeley.edu email address, I will have to invite you individually, so keep that in mind.

- If Google Meet also doesn't work anymore, I'II use a site called

https://explaineverything.com, which is hosted AWS. You'll be able to see a whiteboard and talk to me directly in your web browser, but there's no video.

- In case that also ceases to work, well have audio-only discussion sections on my mumble server. I will send the details when it comes to that.

- In the case of bigger infrastructure disruptions (like a large scale power outage). we're going to have sections using amateur radio: I will use the Mt Diablo repeater station at $147.060 \mathrm{MHz}$ with a PL tone of $100 \mathrm{~Hz}$. My call sign is KN6CDY.

- In case the Bay area becomes uninhabitable, I will move to the wilderness. I plan to still be reachable via APRS, but we'll probably have to move sections to shortwave. In that case, we'll use CW transmission, so practice your Morse code.

Note that a nuclear attack in the upper atmosphere can create very strong electromagnetic fields, so if you want to prepare for that, either use vacuum tube based radios, or store them in a Faraday cage.

\section{I hope this assures you that no matter what happens this semester, I will not let it prevent you from learning quantum mechanics.}

\section{Best wishes, \\ Christian \\ e logistics \\ Good note 10}

Fig. 1. The end of the world is apparently no excuse to miss class.

\section{ICHTML 2020 at a glance}

The International Conference on History, Theory and Methodology of Learning (ICHTML) is a peer-reviewed international conference, which covers interdisciplinary research on education, learning and training, and applications of theories and philosophies used in the sciences of learning and adjacent sciences (Fig. 2).

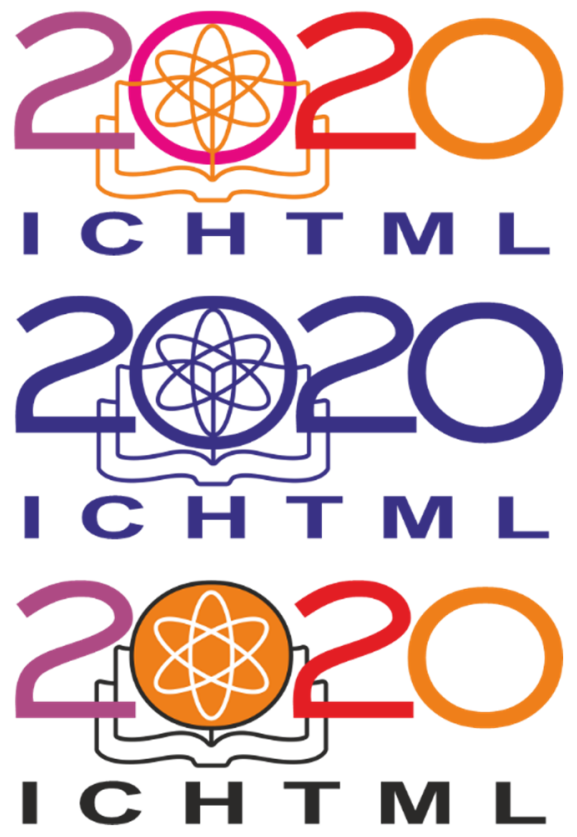

Fig. 2. ICHTML 2020 logos.

The ICHTML occupies contributions in all aspects of psychology of learning, learning theories, learning technologies and tools, paradigms and models and related fields of interest with an emphasis on human and machine learning. The main problematic field of the conference is the current and future issues of modern pedagogical science: psychological and pedagogical, philosophical, socio-cultural aspects of education, learning and training, modern theories, technologies and teaching aids, the emergence of which is determined by globalization, integration processes, social transformations, humanitarian and scientific and technological development. There is urgent general need for principled changes in postclassic education elicited by current theories, models, tools, services, networks and communications.

ICHTML has two presentation levels, Main Conference and Doctoral Consortium. The purpose of the Doctoral Consortium is to orient the PhD students to the world standards of quality of scientific work and to give an opportunity to present their achievements standalone.

ICHTML topics of interest are grouped into 4 tracks:

Track 1: History of Education, Learning and Training

- Evolution of Education, Learning and Training

- Socio-Cultural Determinants of Modern Education Development

- Comparative pedagogy

- Personalia

- World Trends in Learning, Training and Education Development 
Track 2: Theories of Learning, Education and Training

- Analytical Psychology and Learning

- Anthropology of Learning and Cognition

- Comparative Psychology

- Development and Learning

- Developmental Cognitive Neuroscience and Learning

- Discourse and the Production of Knowledge

- Neuropsychology of Learning

- Philosophy of Learning

- Psychology of Learning

- Problems of Preschool, Primary, Secondary, Higher,

Professional and Postgraduate Education

- Lifelong Learning

System

- Theory and Practice of Reforming the Education

- Standardization and Monitoring in Education

- Gender Pedagogy

- Inclusive Education

- Childhood: Problems, Realities and Perspectives

- Formation and Development of Personality

- Theory and practice of profile education

Track 3: Discourses of Learning, Education and

Training

- Philosophy of Education in the System of Socio-

Humanitarian Knowledge

- Education and Civil Society: Trends in Interrelation

- Socio-Cultural Aspects of Teaching Humanitarian

Disciplines in Terms of the Globalization

- Sociological and Economic Factors of Education

Development

- Peculiarities of the Child Development

- Psychological Support of Personality Development

- Psychological Aspects of Educational Content in

Terms of Inclusion

- Educational Management

Track 4: Methodology of Learning, Education and

Training

- Learning Technology

- Artificial Intelligence, Knowledge Engineering, and

Intelligent Tutoring Systems

- Machine Learning, Robot Learning and Artificial

Learning

- Theory of Curricula

- Didactic Systems and Technologies

- Development of the Core Educational Competences
- Assessment in Learning

- Interdisciplinary Dimensions of Learning, Education and Training

- Methodology of Informatization in Education

- Theory and Methodology of Art Education

- STEAM Education

- Methods of Teaching

This volume contains the papers presented at ICHTML 2020: The International Conference on History, Theory and Methodology of Learning held on the May 13-15, 2020 in Kryvyi Rih, Ukraine.

There were 133 submissions. Each submission was reviewed by at least 3 , and on the average 3.9 , program committee members. The committee decided to accept 44 papers.

\section{ICHTML 2020 venue}

Kryvyi Rih State Pedagogical University has 90-year experience in training generations of specialists for the state and public needs (Fig. 3). Nowadays Kryvyi Rih State Pedagogical University is a center of innovative educational and methodological research, scientific and cultural center of the Kryvyi Rih and Dnipropetrovsk region, entrusted with the mission of training highly competitive professional teachers for all parts of the education sector. University graduates hold the administrative, state, cultural, environmental protection positions. They work effectively in different spheres such as education, chemistry, sociology, psychology, technology, design, tourism, translation, journalism, publishing and sports [7].

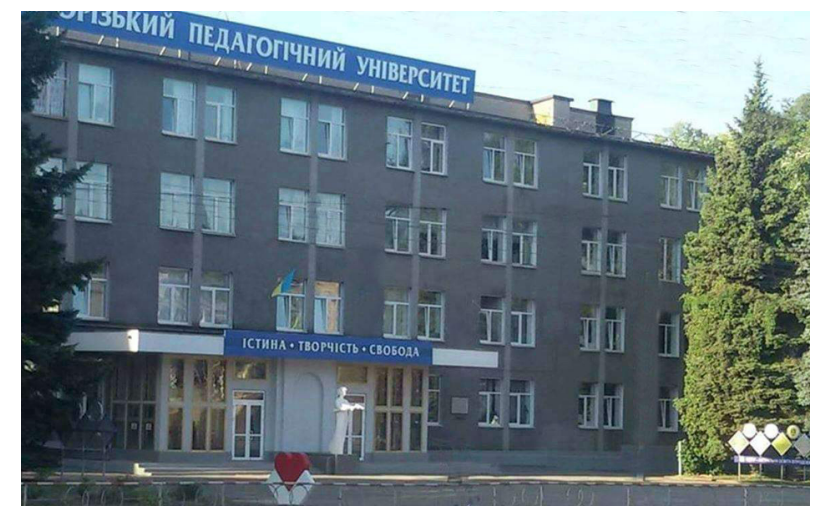

Fig. 3. Kryvyi Rih State Pedagogical University main building

\section{ICHTML 2020 program committee}

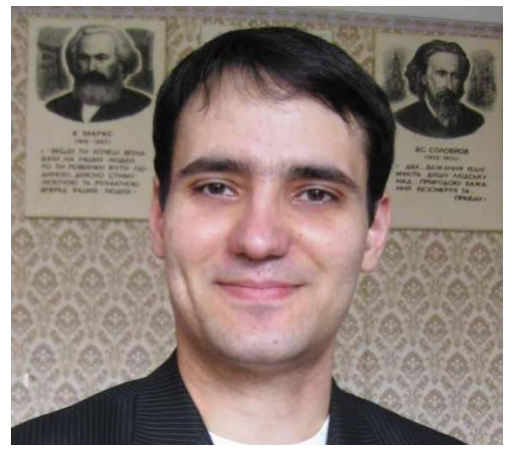

Dr. Andrii Abdula, Kryvyi Rih State Pedagogical University, Ukraine

WWW: https://kdpu.edu.ua/personal/aiabdula.html 


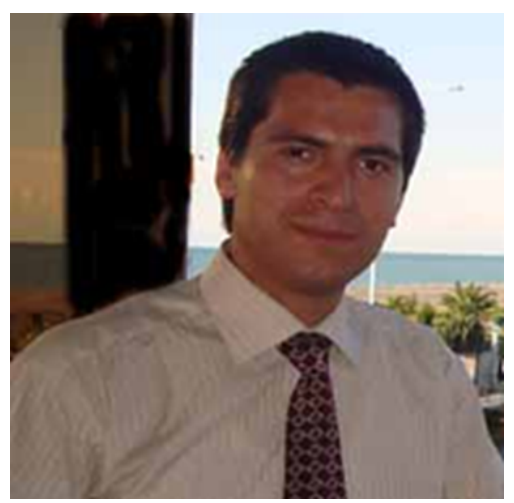

Dr. George Abuselidze, Professor of Economics and Business, Department of Finance, Banking and Insurance, Batumi Shota Rustaveli State University, Batumi, Georgia

George Abuselidze, from the Batumi Shota Rustaveli State University (in 2001) and Ivane Javakhishvili Tbilisi State University, Georgia, in 2005, and a Doctor of Economics Sciences degree (Dr. habil.) from the National Academy of Sciences of George, in 2005. Since 2002, he has been working in the Finance and Banking at the Ivane Javakhishvili Tbilisi State University, since 2006 - Batumi Shota Rustaveli State University where he is currently Head department of Finance, Banking and Insurance. His research interests include Economics, Econometrics, Finance and Social Sciences (miscellaneous). He has published a number of papers in international journals and volumes in book series, is a member of editorial or/and review boards of Oeconomia Copernicana, Journal of Financial Economic Policy, International Journal of Economics and Finance, journal of Science and studies of accounting and finance: problems and perspectives, Management Studies and etc. He also played instrumental role in different prestigious internal collaborative research project with USA, Canada, Lithuania, Poland, Ukraine, Turkey and etc.

WWW: https://orcid.org/0000-0002-5834-1233

E-mail: george.abuselidze@bsu.edu.ge

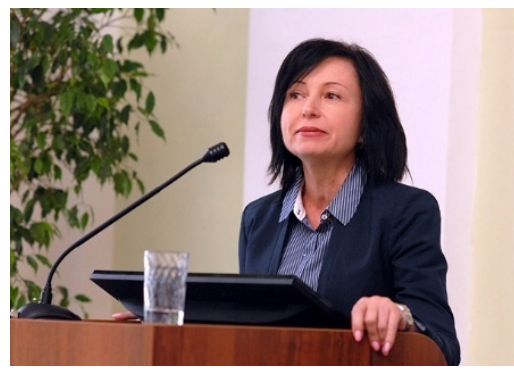

Dr. Svitlana Amelina, Doctor of Education, Professor, Head of the Department of Foreign Philology and Translation, National University of Life and Environmental Sciences of Ukraine, Kyiv, Ukraine

Svitlana Amelina, born in 1961, received a Candidate of Philological Sciences degree (Dr. phil.) in 1994 and a Doctor of Pedagogical Sciences degree (Dr. habil.) in 2009. She studied at the Humboldt-Universität zu Berlin, trained at the largest universities in Germany and France. Since 2012, she has been working at the National University of Life and Environmental Sciences of Ukraine. Her research interests include theory and methodology of professional education; pedagogy of higher school; methods of teaching foreign languages and translation; syntax, semantics and pragmatics of the Germanic languages. She participated in numerous scientific-theoretical and scientific-practical conferences. She was a member of numerous scientific-theoretical and scientificpractical conferences. She is the author of many scientific publications, including monographs, articles, and reports.

E-mail: svetlanaamelina@ukr.net

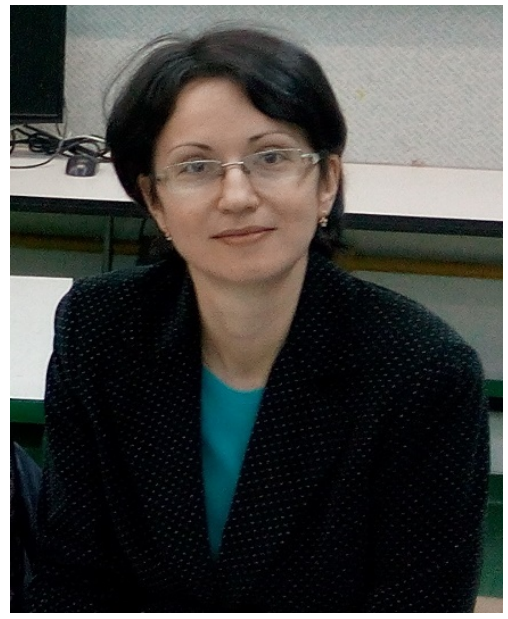

Dr. Vira Andriievska, Associate Professor, Department of Informatics, H. S. Skovoroda Kharkiv National Pedagogical University, Kharkiv, Ukraine

Vira Andriievska, born in 1980, received a Candidate of Pedagogical Sciences degree (2009) and a Doctor of Pedagogical Sciences degree (2019) from the H.S. Skovoroda Kharkiv National Pedagogical University. Since 2004, she has been working in the field of primary education at the H.S. Skovoroda Kharkiv National Pedagogical University. Her research interests include training future primary school teachers to use ICT in their professional activities. Present research interests include the project-based learning and STEM education. She has published a number of papers in international journals.

WWW: http://kafinfo.org.ua

E-mail: andvera80@gmail.com 


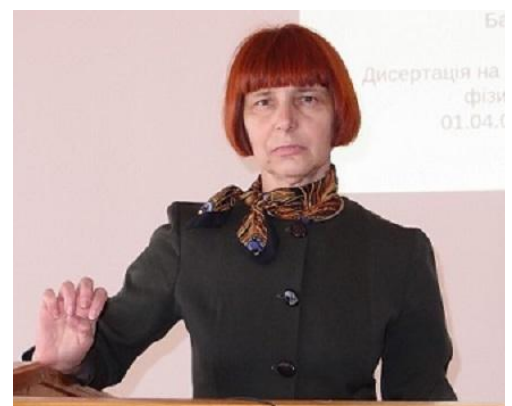

Prof. Ruslana Balabai, Kryvyi Rih State Pedagogical University, Ukraine

WWW: https://kdpu.edu.ua/personal/rmbalabai.html

Dr. Liudmyla Bilousova, Full Professor of Computer Science Department at H. S. Skovoroda Kharkiv National Pedagogical University, Ukraine

Liudmyla Bilousova got a M.A. in Radio-physics from Kharkiv State University, USSR (1959), and PhD in physical-mathematical science from Kharkiv State University, USSR (1970). Liudmyla Bilousova headed Computer Science Department at G.S. Skovoroda Kharkiv National Pedagogical University for 27 years (1991-2018). She is a founder and a head of her scientific school on the problems of development of Informatics education and the implementation of innovative technologies in educational process. In the framework of the school a series of $\mathrm{PhD}$ and doctoral research has been completed. Dr. Liudmyla Bilousova is a scientific supervisor of $21 \mathrm{PhD}$ theses. She is an author of about 400 scientific and methodical works including 1 collective monograph and 64 tutorials. Liudmyla Bilousova is a program committee member of International Conference ICTERI-2019 and International Workshop CTE.

WWW: http://hnpu.edu.ua/uk/bilousova-lyudmyla-ivanivna E-mail: lib215@gmail.com

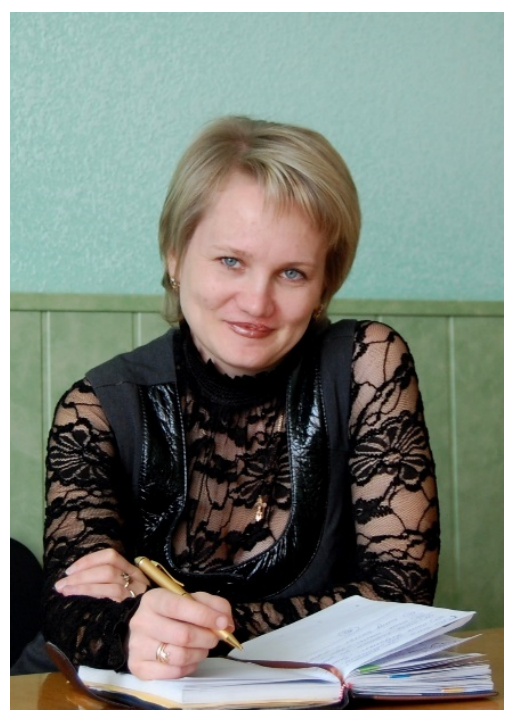

Dr. Olga Bondarenko, Candidate of Pedagogical Sciences, Associate Professor, Department of Economic and Social Geography and Methods of Teaching, Kryvyi Rih State Pedagogical University, Kryvyi Rih, Ukraine

Olga Bondarenko, born in 1979, in 2001 graduated with honors from the geographical faculty of Krivoy Rog State Pedagogical University, majoring in "Pedagogy and Methodology of Secondary Education. Geography and Biology", acquired Bachelor Degree. In 2002 she received a Master Degree with honors in the major "Pedagogy and Methodology of Secondary Education. Geography", qualified as a teacher of geography. In 2009, she successfully defended her PhD thesis at the Republican Higher Educational Institution "Crimean Humanities University" (Yalta) and received a PhD in Pedagogical Sciences. Since 2005 he has been working at Kryvyi Rih State Pedagogical University. Author of a number of scientific publications on vocational education, training of future teachers for pedagogical activity. Her research interests include teacher training, the use of ICTs and GIS technologies in the educational process.

WWW: https://kdpu.edu.ua/personal/ovbondarenko.html E-mail: bondarenko.olga@kdpu.edu.ua

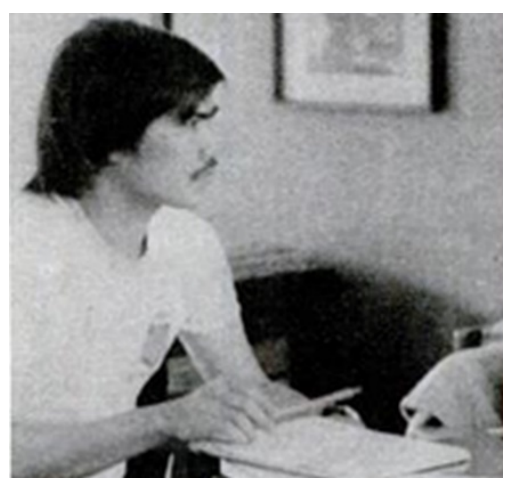

WWW: https://www.linkedin.com/in/allen-del-carmen-a3b36519/ 


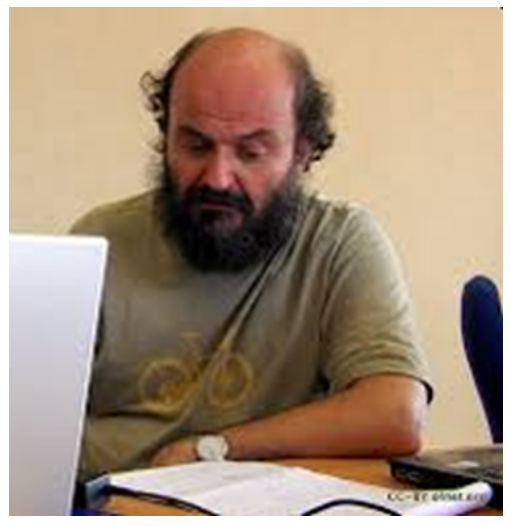

Dr. Yannis Dimitriadis is Full Professor of Telematics Engineering and ex Dean of the Doctoral School, University of Valladolid, Spain. He is also the coordinator of the GSIC/EMIC research group, an inter-disciplinary group, integrating over 20 researchers and practitioners from the field of Information and Communications Technologies (ICT) and Pedagogy.

His recent research work has focused on learning analytics and smart learning environments, alignment of learning design and learning analytics, design patterns, conceptual and technological support to the orchestration of computersupported collaborative learning processes, active pedagogies at scale, and acrossspaces (Web, 3D worlds and augmented reality) learning. He has participated in more than 50 competitive research projects on technology-enhanced learning, coauthored more than 80 journal papers and 200 conference papers, and organized several workshops and symposia, such as the ECTEL 2019 workshop on Hybrid Learning Spaces, CSCL 2015 invited symposium on computer science challenges in CSCL, or the ICLS 2012 workshop on classroom orchestration. Dr. Dimitriadis is a senior member of IEEE, and member of ISLS, and spent his most recent sabbatical year (2017-2018) at Berkeley, University of Edinburgh, and EPFL.

WWW: https://www.gsic.uva.es/members/yannis

E-mail: yannis@tel.uva.es

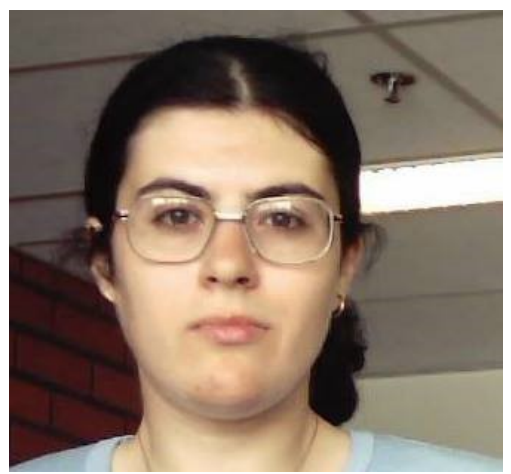

Prof. Irina Georgescu, Academy of Economic Studies, Romania

Irina Georgescu holds a $\mathrm{PhD}$ in Economics from Turku Centre for Computer Science, Åbo Akademi, Turku, Finland. Currently she is with the Department of Economic Informatics and Cybernetics at Faculty of Cybernetics, Statistics and Economic Informatics from the Bucharest Academy of Economic Studies. Her research interests lie in the area of fuzzy sets and systems, social choice and welfare and risk theory. She has published 2 books in Springer Verlag and about 30 journal papers on fuzzy choice functions and possibilistic risk theory.

WWW: https://www.researchgate.net/profile/Irina_Georgescu

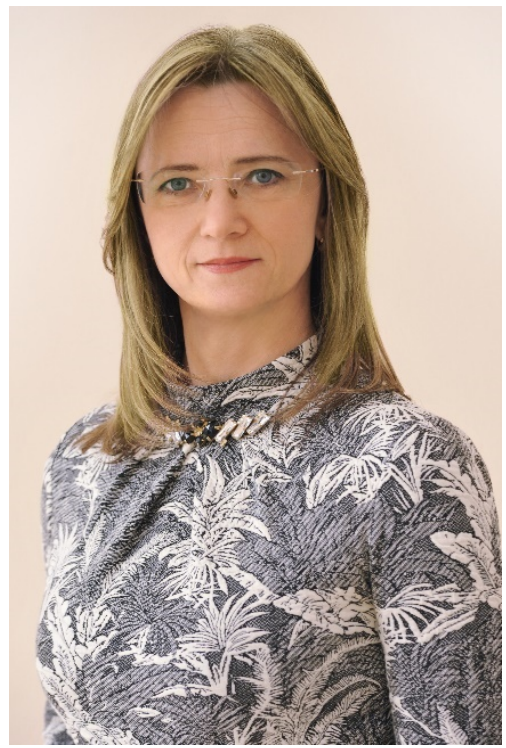

Dr. Olena Glazunova, Professor of ICT in Education, Department of Information Technologies, National University of Life and Environmental Sciences of Ukraine

Olena Glazunova, received a Candidate of Pedagogical Sciences degree (Dr. phil.) in 2003, and a Doctor of Pedagogical Sciences degree (Dr. habil.) from the Institute of Informational Technologies and Tools in Education NAPS of Ukraine in 2015. Since 2003, she has been working in the field of design and development of cloud-based scientific-educational environment of the university, use of technologies of inquiry-based and project-based activities and implementation of teamwork approaches in IT-students learning, transfer and modification of educational methods to specialized teaching of research masters' programs and courses of e-learning management.

WWW: https://nubip.edu.ua/IT.NUBIP

E-mail: o-glazunova@nubip.edu.ua 


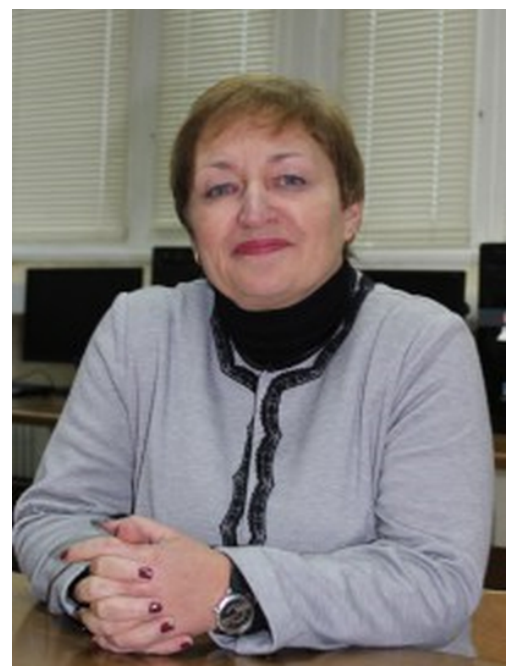

Dr. Liudmyla Gryzun, Full Professor of Computer Science Department at H. S. Skovoroda Kharkiv National Pedagogical University, Ukraine.

Liudmyla Gryzun earned a M.A. in Applied Mathematics from the Kharkiv State University, USSR (1986); PhD and Second Doctoral Degree in Pedagogical science from G.S. Skovoroda Kharkiv National Pedagogical University (Ukraine). The sphere of her research is focused on the curriculum and educational content design in higher education, the process of curriculum disciplines structuring, based on scientific knowledge integration; AI application to pedagogical problems solution; IT tools for inquiry-based and holistic learning etc. She is an author of more than 110 scientific and methodical works including 1 monograph and 5 tutorials. Liudmyla Gryzun has delivered a number of Keynote presentations at the International conferences: 2018 ICTEL (Rome, Italy), 2018 ICRTEL (Barcelona, Spain), 2019 ICSTR (Rome, Italy) and others. She is also a reviewer of the foreign journals: Athens Journal of Education, IJIRES (International Journal of Innovation and Research in Educational Sciences), and PEOPLE: International Journal of Social Sciences.

Profile Weblinks:

http://hnpu.edu.ua/uk/gryzun-lyudmyla-eduardivna

https://www.linkedin.com/in/liudmyla-gryzun-68769280/

https://www.researchgate.net/profile/Liudmyla_Gryzun

E-mail: Lgr2007@ukr.net

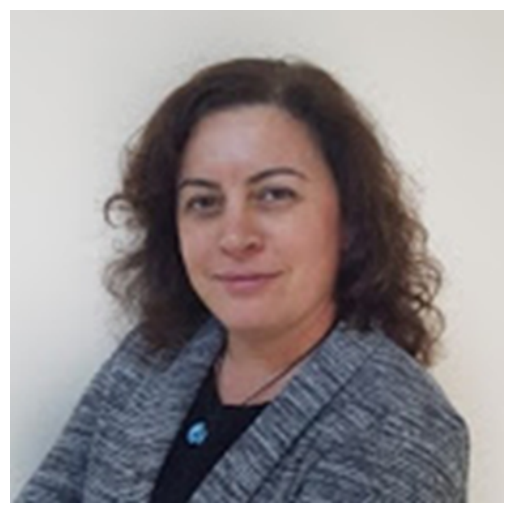

Dr. Yasemin Gulbahar, Professor of Computer Education, Department of Computer Education and Instructional Technology, Ankara University, Ankara, Turkey

Dr. Gulbahar has got her BS degree from Department of Mathematics of Science Faculty at Middle East Technical University (METU) in 1992. Same year she started working as a programmer at METU Computer Center. Then, in 1998, she became a research assistant to the Department of Computer Education and Instructional Technologies (CEIT) in the Faculty of Education, METU while studying her MS degree at the same department. She earned his MS degree in the field of Science Education at METU Graduate School of Science in 1999 and she received her $\mathrm{PhD}$ in Department of Computer Education and Instructional Technologies (CEIT) from Graduate School of Sciences in 2002. After, she worked for Başkent University Faculty of Education Department of Computer Education and Instructional Technologies (CEIT) for about 9 years. Between years 2011-2017 she worked in Ankara University as the head of Department of Informatics and meanwhile served as the Chairman of Distance Education Center. Since 2018 she is a faculty member of Faculty of Educational Sciences in the Department of Computer Education and Instructional Technologies (CEIT). Dr. Gulbahar has got her Associate Professor degree in 2009 and full Professor Degree in 2014.

Yasemin Gulbahar has lectured on many topics such as programming languages, problem solving and algorithms, instructional technologies, instructional design, material design and development, distance learning, web design, measurement and evaluation, research methods, teaching methods, software development, technology integration and planning both in undergraduate and graduate level. She has also many national and international publications as books, book chapters, journal articles and proceeding papers.

WWW: http://cv.ankara.edu.tr/gulbahar@ankara.edu.tr E-mail: gulbahar@ankara.edu.tr 

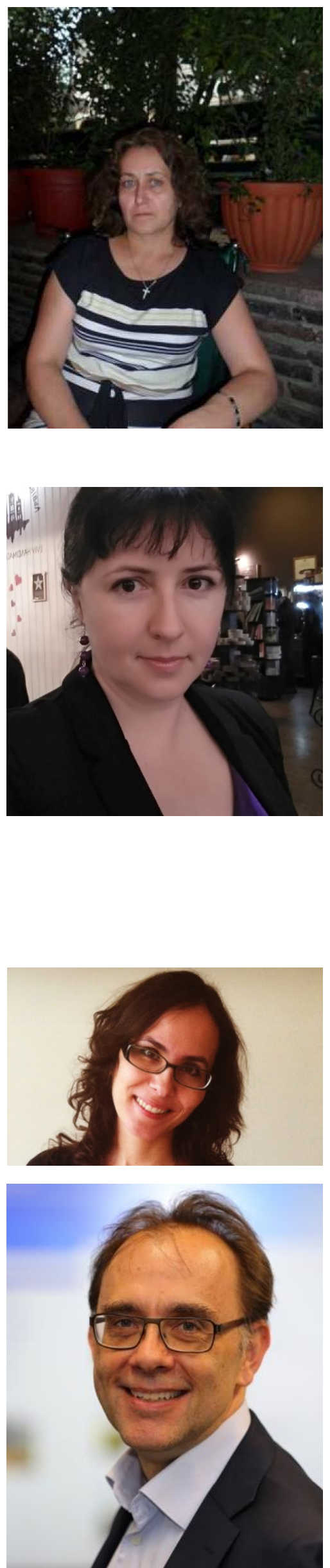

Prof. Vita Hamaniuk, Doctor of science (pedagogical sciences), professor of the Department of German, Literature and Didactics, Kryvyi Rih State Pedagogical University, Kryvyi Rih, Ukraine

Vita Hamaniuk, born in 1965, Education - Dnipropetrovsk State University (1988), received a Candidate of Pedagogical Sciences degree $(\mathrm{PhD})$ from the Charkiv National Pedagogical Skovoroda University, Kryvyi Rih, Ukraine, in 1995, a Doctor of Sciences degree from East-Ukrainian National Wolodymyr Dahl University, Lugansk, Ukraine, in 2013. Since 2002 has been working at the Department of German, Literature and didactics at the Kryvyi Rih State Pedagogical University where she is currently professor. Her research interests include foreign languages teaching and learning, didactics of multilingualism, elearning, blended learning, comparative researches in Education. She has published a number of papers in Ukrainian and international journals, actively participates in international conferences and projects.

WWW: https://kdpu.edu.ua/personal/vagamanuk.html E-mail: vitana65@gmail.com

Dr. Anna Iatsyshyn, Leading Researcher, Department of open education and scientific information systems, State Institute of Information Technologies and Learning Tools of the National Academy of Educational Sciences of Ukraine, Kyiv, Ukraine.

Anna Iatsyshyn, born in 1984, received a Candidate of pedagogical sciences degree from the Institute of Teacher Education and Adult Education of the National Academy of Educational Sciences of Ukraine, in 2009. A. Iatsyshyn is actively engaged in scientific activities in investigates the use of digital systems for: postgraduate training, research, scientometrics, image formation of scientists and organization. Features of ICT implementation in inclusive education and teacher training. She has published a number of papers in journals and monographs, is a member of associate editors of Information Technologies and Learning Tools is a bimonthly peer-reviewed e-journal in educational sphere, published full-text articles online with immediate open-access.

WWW: http://iitlt.gov.ua/structure/departments/science/detail.php?ID=53

E-mail: anna13.00.10@gmail.com

Dr. Hale Ilgaz, Ankara University, Turkey

WWW: https://www.researchgate.net/profile/Hale_Ilgaz

\section{Prof. Michael Kerres, University Duisburg-Essen, Germany}

Since 2001, Michael Kerres is full professor of educational science at University Duisburg-Essen, Germany. He holds the chair of educational media and knowledge management and is director of the university's Learning Lab. From 1998-2001, he has been a professor of educational psychology at Bochum University, and from 1990 to 1998 professor of educational technology at Furtwangen University of Applied Sciences. In 1983, he has earned a doctoral degree in psychology at Bochum University and in 1988, he finished his habilitation (post-doctoral thesis) at University of Education in Freiburg. His present research interests include digital transformation of education, instructional designs for digital learning and learning infrastructures.

WWW: https://learninglab.uni-due.de/ 

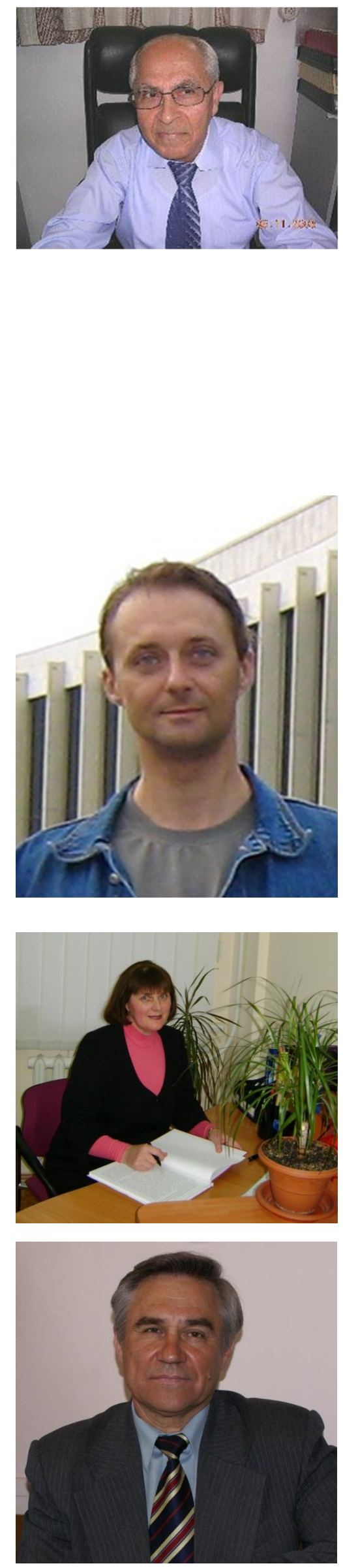

Prof. Arnold Kiv, Ben-Gurion University of the Negev, Israel

Arnold Kiv received the D. Sc. (Dr. Hab.) degree in solid state physics from Tartu Institute of Physics, in 1978. From 1964 to 1982, he was a Senior Researcher and a Head of the Laboratory of Radiation Effects, Institute of Nuclear Physics, Academy of Sciences, Uzbekistan. From 1983 to 1998, he was a Head of the Department of Theoretical Physics, South-Ukrainian National Pedagogical University. In 1997 he was an Invited Professor, Western Ontario University, Canada. From 1999 to the present, he is a Professor-Researcher in the Department of Materials Engineering, Ben-Gurion University of the Negev, Israel. In 1996 and 2011 he was co-Director of NATO Advanced research Workshops and an Editor of two NATO Series books. He has about 300 publications, three monographs and three Invention Certificates in the field of radiation effects in solid state electronics. His research interests include mechanisms of formation of radiation defects in solids, radiation methods in microelectronics, computer simulation in natural and humanitarian sciences.

WWW: https://www.researchgate.net/profile/Arik_Kiv

Dr. Oleksandr Kolgatin, Professor of Information System Chair, Department of Economic Informatics, Simon Kuznets Kharkiv National University of Economics, Kharkiv, Ukraine

Oleksandr Kolgatin received a Candidate of Technical Sciences degree (PhD) from the Low Temperature Physics and Engineering of the National Academy of Sciences of Ukraine in 1995 and a Doctor of Pedagogical Sciences degree from the Institute of Information Technologies and Learning Tools of the National Academy of Educational Sciences of Ukraine in 2011. His research interests include computational modelling, information and communication technologies in education, and pedagogical diagnostics. He has published a number of papers in Ukrainian and international journals, is a member of editorial boards of Journal of Information Technologies in Education and an associate editor of Information Technologies and Learning Tools.

WWW: https://orcid.org/0000-0001-8423-2359

Prof. Zhanna Koloiz, Kryvyi Rih State Pedagogical University, Ukraine

WWW: https://kdpu.edu.ua/personal/zhvkoloiz.html

Prof. Oleksandr Konoval, Kryvyi Rih State Pedagogical University, Ukraine

WWW: https://kdpu.edu.ua/personal/oakonoval.html 

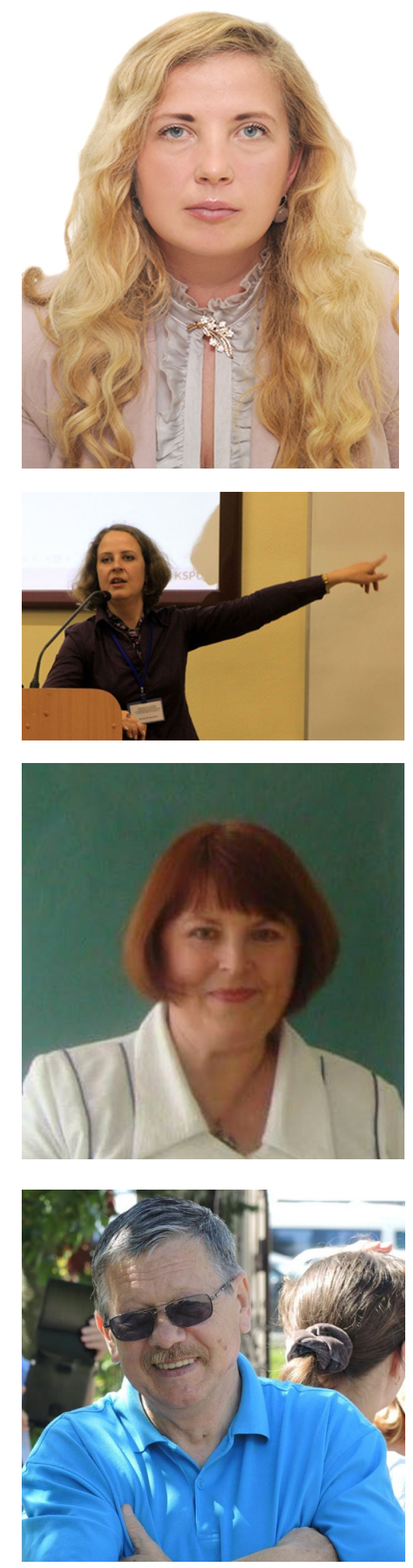

E-mail: kramarenko.tetyana@kdpu.edu.ua

Dr. Volodymyr Kukharenko, Professor of Technical Cryophisics Department, National Technical University "Kharkiv Polytechnic Institute”, Kharkiv, Ukraine

Volodymyr Kukharenko, born in 1947, received a Candidate of Technical Sciences degree from Physical Technic Institute of Low Temperature National Academy of Sciences of Ukraine. Since 1976, he has been working in the field of low temperature at the National Technical University "Kharkiv Polytechnic Institute", where he is professor of Technical Cryophysics Department and academician of International Academy of Refrigeration UD. His research interests include distance learning. He has published a number of papers in international journals and six books from creating distance courses, about tutor, blended learning.

WWW: https://dl.khpi.edu.ua

E-mail: kukharenkovn@gmail.com

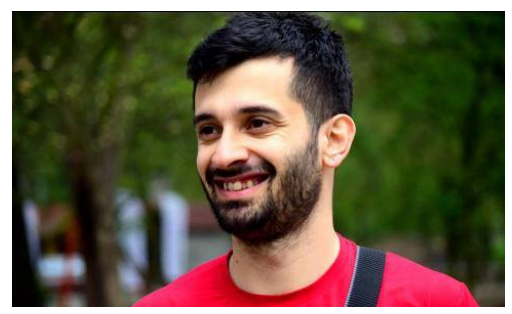

WWW: https://egitim.amasya.edu.tr/personel/akademik-personel?id=1659 

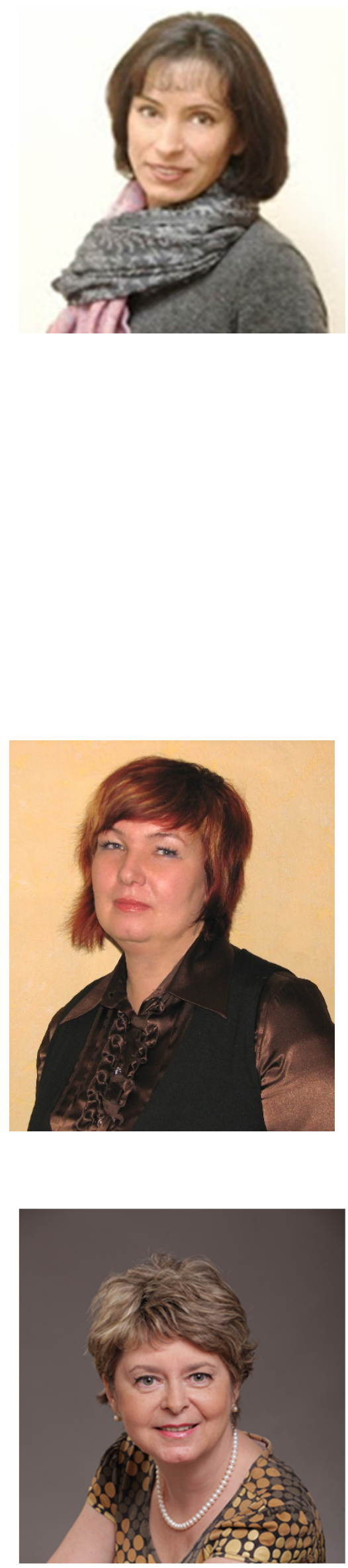

Dr. Olena Kuzminska, Associate Professor of Information Technology and Distance Learning Department, National University of Life and Environmental Sciences of Ukraine, Kyiv, Ukraine

Olena Kuzminska, born in 1970, received a Candidate of Pedagogic Sciences degree (PhD) from the National Pedagogical Dragomanov University (Kyiv) in 2008. Since 2008, she has been working at the National University of Life and Environmental Sciences of Ukraine, where she is currently head of Information Technology and Distance Learning Department. She has experience in research and teaching in: design and development of innovative blended and distant elearning technologies, instructional design; development of programs and organization of trainings for teachers and students on efficient use of information \& communicational technologies (ICT) in education and research; use of technologies of inquiry-based and project-based activities and implementation of teamwork approaches as a tool for development of digital competences; transfer and modification of education methods to specialized teaching of research masters' programs and courses of e-learning management and scholarly communication. She research interests also include design and integration of scholarly communication tools to digital educational environment of university; integration of Microsoft and Google cloud services with e-learning process and postgraduate training. She has published a number of papers in international journals and volumes in book series, is a member of program committee of ICTERI (International Conference on ICT in Research, Education and Industrial Applications).

WWW: https://nubip.edu.ua/node/3900, https://cutt.ly/9thm8Un

E-mail: o.kuzminska@nubip.edu.ua

Dr. Olena Lavrentieva, Full Professor, Head of General Sciences and Vocational Training Department, Kryvyi Rih State Pedagogical University, Kryvyi Rih, Ukraine

Olena Lavrentieva, born in 1968, received a Candidate of Pedagogical Sciences degree (Dr. phil.) from the Lesya Ukrainka East European National University, Ukraine, in 2005 by specialty 13.00.09 "Theory of Education", and a Doctor of Pedagogical Sciences degree (Dr. habil.) from the Institute of Teacher Education and Adult Education of the National Academy of Sciences of Ukraine by specialty 13.00.04 "Theory and Methods of Professional Education", in 2015. Since 2003, she has been working in the Kryvyi Rih State Pedadogical University, where she is currently head of department. Her research interests include didactic and methodology issues of vocational training process. She has published a number of papers in international journals and volumes in book series, is a member of editorial boards of Physical and Mathematical education.

\section{E-mail: helav68@gmail.com}

Prof. Olena Lokshyna, Dr. Sc., Head of the Department of Comparative Education, Institute of Pedagogy of the National Academy of Educational Sciences of Ukraine, Kyiv, Ukraine

Olena Lokshyna, born in 1959, received a Candidate of Educational Sciences degree (Dr. phil. in Education) in 1992, and a Doctor of Sciences degree (Dr. habil. in Education) from the Institute of Pedagogy of the National Academy of Educational Sciences of Ukraine, in 2011. She has been working in the area of comparative and international education at the Institute of Pedagogy of the National Academy of Educational Sciences of Ukraine since 1990. She received her Professor rank in 2015 and was elected as a Corresponding Member of the National Academy of Educational Sciences of Ukraine in 2019.

Her research interests focus on developmental trends and innovations in education in Ukraine and abroad through the lens of comparison, with special interest in reforms, curricula, competences, students' assessment, education quality 


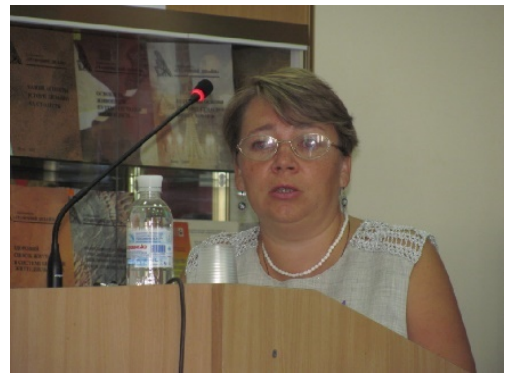

monitoring, VET, methodology of comparative education research, education policy analyses. Olena Lokshyna is an author/co-author of about 300 works monographs and analytical studies, textbooks and course outlines, journal papers and conference abstracts. She teaches courses on comparative and international education for PhD students at the Institute of Pedagogy and at Borys Grinchenko Kyiv University. She is a member of the editorial boards of the Ukrainian Pedagogical Journal, Education Modern Discourses Journal and Studies in Comparative Education Journal.

WWW: http://undip.org.ua/

E-mail: luve2001@hotmail.com

Dr. Iryna Lovianova, Doctor of Pedagogical Sciences, Professor of the Department of Mathematics and Methods of its Teaching, Kryvyi Rih State Pedagogical University, Kryvyi Rih, Ukraine

Irina Lovianova received a Candidate of Pedagogical Sciences degree (Dr. ph.) from the Institute of Pedagogical of the National Academy of Sciences of Ukraine, in 2006, and a Doctor of Philosophical Sciences degree (Dr. habil.) from the The Bohdan Khmelnytsky National University of Cherkasy in 2015. Since 2001, she has been working in the field of didactics of mathematics at the Kryvyi Rih State Pedadogical University. The range of interests is the issues of Education, math education, methodology for teaching mathematics. She has published a number of papers in international journals and collective monographs.

\section{E-mail: lovyanova.iryna@kdpu.edu.ua}

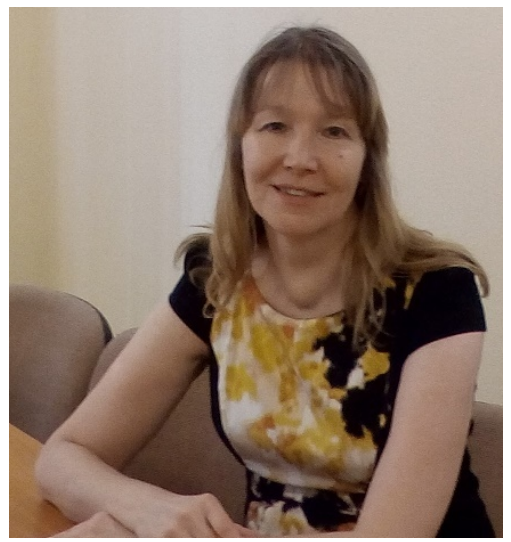

Dr. Svitlana Lytvynova, Head of the Open Learning Environment Technology Department, Institute of Information Technologies and Learning Tools of the National Academy of Education Sciences of Ukraine, Kiev, Ukraine

Svitlana Lytvynova, born in 1964, in 2011 received a degree of Candidate of Pedagogical Sciences $(\mathrm{PhD})$ at the Institute of Information Technologies and Learning Tools of the National Academy of Education Sciences of Ukraine. In 2017, received a degree of Doctorate of Pedagogical Sciences at the Institute of Information Technologies and Learning Tools of the National Academy of Education Sciences of Ukraine. Since 2004, she has been working on the development, implementation and use of information and communication technologies in educational practice. Her research interests include improving the quality of the educational environment of educational institutions and the continuous development of educators. She is a MIE Expert Microsoft Education. She has published a number of articles in international scientific journals and book series volumes, is a member of the editorial boards of the journal "Information Technologies and Teaching Tools" (Web of Science) and the professional publication "Computer at School and Family".

WWW: https://www.facebook.com/slytvynova E-mail: s.h.lytvynova@gmail.com

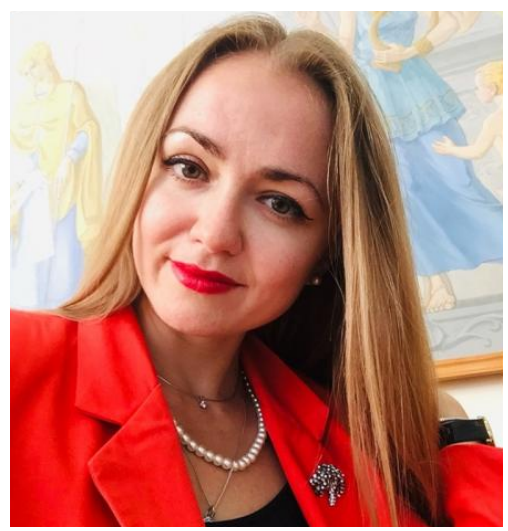

Dr. Iryna Makarenko, Kryvyi Rih State Pedagogical University, Ukraine

WWW: https://kdpu.edu.ua/personal/i_e_makarenko.html 

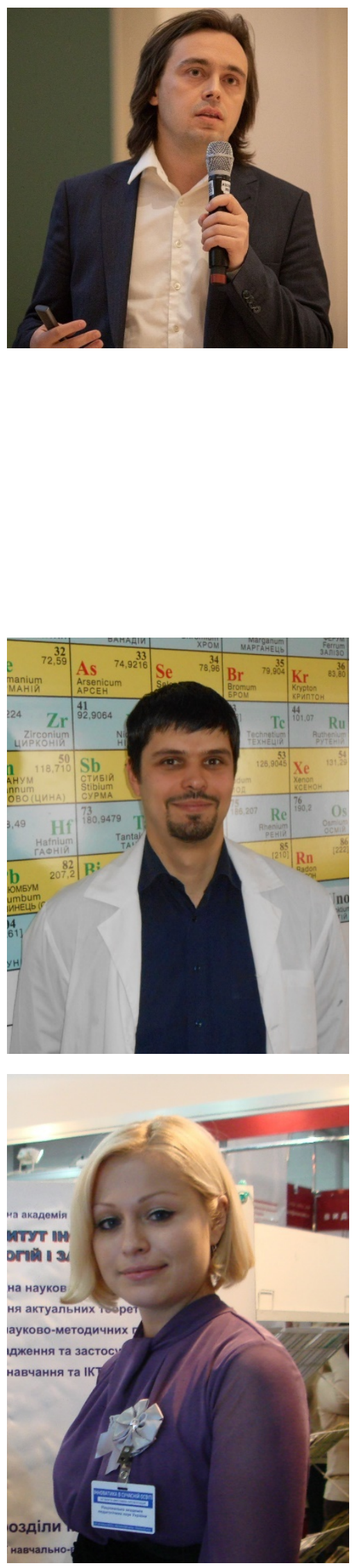

Dr. Andriy Matviychuk, Professor of Economic and Mathematical Modeling, Kyiv National Economic University named after Vadym Hetman, Kyiv, Ukraine

Andriy Matviychuk, born in 1978, became a Candidate of Science in Economics $(\mathrm{PhD})$ by specialty Economic and Mathematical Modelling at the Technological University of Podillia (Khmelnitskiy) in 2003, and a Doctor of Economics (DSc) with a degree in Mathematical Methods, Models and Information Technologies in Economics at the Kyiv National Economic University named after Vadym Hetman in 2008.

Since 1990 he has been working in the field of AI \& ML at the Kyiv National Economic University named after Vadym Hetman, where he is currently professor of Economic and Mathematical Modeling Department, director of Institute of Modeling and Informational Technologies in Economics and CEO at KNEU Science Park.

His research interests cover the field of mathematical modeling of complex systems, primarily using tools of neural networks and fuzzy logic. He is a Chief Editor of scientific and analytical journal Neuro-Fuzzy Modeling Techniques in Economics and a member of editorial boards of a number of scientific journals.

WWW: https://kneu.edu.ua/ua/depts9/k_ekon_matematychn_modeljuvannja/vy kladachi_kmm/Matvijchuk.A.V/

E-mail: editor@nfmte.com

Dr. Pavlo Nechypurenko, Assistant Professor of Department of Chemistry and Methods of its Teaching, Kryvyi Rih State Pedagogical University, Kryvyi Rih, Ukraine

Pavlo Nechypurenko, born in 1981, received a Magister of Teaching of Chemistry from Kryvyi Rih State Pedagogical University, Ukraine, in 2004, and a Candidate of Pedagogical Sciences degree (Dr. phil.) from the Luhansk Taras Shevchenko National University, Ukraine, in 2017. Since 2004, he has been working in the field of analytical chemistry and method of solving chemical problems at the Kryvyi Rih State Pedagogical University. His research interests include using of ICT on Chemistry education, Analytical Chemistry, Technique of chemical experiment. He has published a number of papers in Ukrainian and international journals and developed a series of virtual laboratory work to teaching chemistry.

E-mail: acinonyxleo@gmail.com, acinonyxleo@kdpu.edu.ua

Dr. Yulia Nosenko, Leading Researcher, Department of Cloud-Oriented Systems of Education Informatization, Institute of Information Technologies and Learning Tools of NAES of Ukraine, Kyiv, Ukraine

Yulia Nosenko, born in 1984, received a Candidate of Pedagogical Sciences degree (Dr. phil.) in 2011. In 2010-2015 worked at Taras Shevchenko National University of Kiev (part time). Since 2010 has been working at the Institute of Information Technologies and Learning Tools of National Academy of Educational Sciences of Ukraine, where she is currently leading researcher. Her research interests relates to implementation and use of cloud services in education, formation and development of educators' digital competence, use of ICT as a tool for supporting inclusive learning.

She has published over 70 scientific papers, including articles in international journals, is a member of editorial board of peer-reviewed e-journal "Information Technologies and Learning Tools".

WWW: http://iitlt.gov.ua/structure/departments/cloud/detail.php?ID=48

E-mail: nosenko@iitlt.gov.ua 


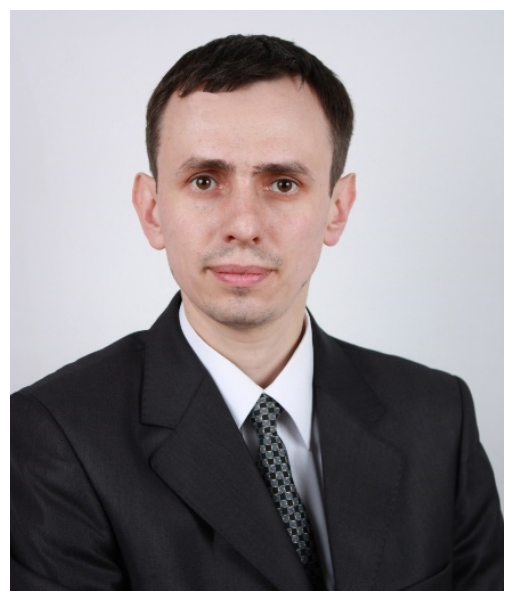

Dr. Vasyl Oleksiuk, $\mathrm{PhD}$ (pedagogical sciences), associate professor of the Department of Computer Science and Teaching Techniques, Ternopil Volodymyr Hnatiuk National Pedagogical University, Ternopil, Ukraine

Vasyl Oleksiuk, born in 1980, received a Candidate of Pedagogical Sciences degree (Dr. phil.) from the National Pedagogical University, Kyiv, Ukraine, in 2007. Since 2003, he has been working Department of Computer Science and Teaching Techniques at Ternopil Volodymyr Hnatiuk National Pedagogical University, where he is currently associate professor. His research interests include computer networks, cloud computing, e-learning, electronic libraries. $\mathrm{He}$ has published a number of papers in Ukrainian and international journals, is a member of editorial boards of the journals Information Technologies and Learning Tools (Institute of Information Technologies and Learning Tools of NAES of Ukraine) and The Scientific Issues of Ternopil Volodymyr Hnatiuk National Pedagogical University (Series: pedagogy).

WWW: http://kafinf.tnpu.edu.ua/en/teachers/oleksuk_v-p/\# E-mail: oleksyuk@fizmat.tnpu.edu.ua

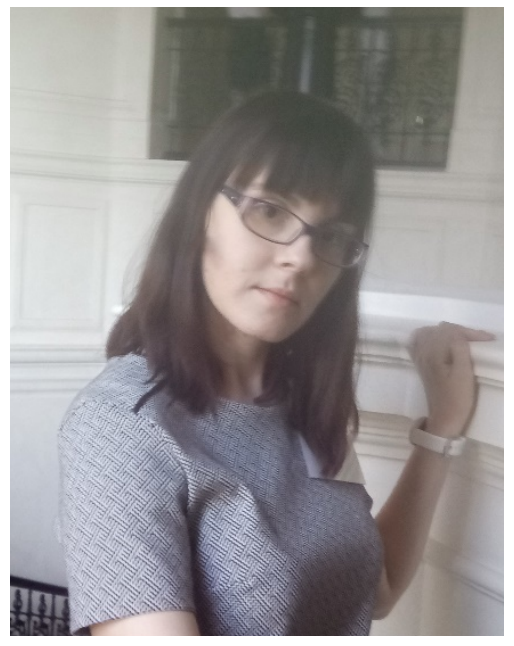

Olena Olifer, assistant lecturer, Department of Phylosophy, Kryvyi Rih State Pedadogical University, Kryvyi Rih, Ukraine

Olena Olifer, born in 1993, received a master's degree from Kryvyi Rih National University in 2015. At the moment she is working on her $\mathrm{PhD}$ thesis "Language bases of socio-cultural personal identity". Her research interests include analytic philosophy, British philosophy, and philosophy of language.

E-mail: olifer.olena@kdpu.edu.ua

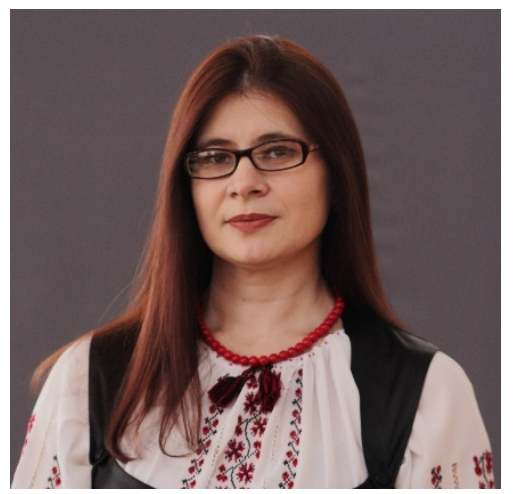

Dr. Kateryna Osadcha, Full professor, Department of Computer Science and Cybernetics, Bogdan Khmelnitsky Melitopol State Pedagogical University, Melitopol, Ukraine

Kateryna Osadcha, born in 1977, received a Candidate of Pedagogical Sciences (PhD in Education) from the Vinnytsia State Pedagogical University named after Mykhailo Kotsiubynsky, Ukraine, in 2010. Since 2011, she has been working as a professor of the Department of Computer Science and Cybernetics at the Bogdan Khmelnitsky Melitopol State Pedagogical University.

Her research interests include: computer science, network technology, programming, ICT, e-learning, engineering education, educational technology, tutoring. She is author of about a hundred scientific works, including textbooks, monographs, author's certificates. She is a member of editorial boards of "Ukrainian Journal of Educational Studies and Information Technology" (Ukraine), "International Conference on Higher Education Advances" (Spain), "Transactions of Kremenchuk Mykhailo Ostrohradskyi National University" (Ukraine), "Professional Education: Methodology, Theory and Technologies" (Ukraine).

WWW: https://www.facebook.com/kosadca E-mail: okp@mdpu.org.ua 


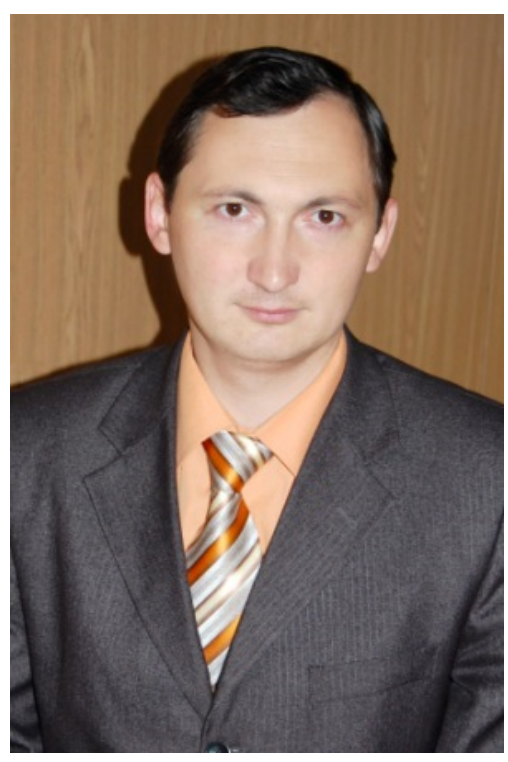

Dr. Viacheslav Osadchyi, Professor of Department of Computer Science and Cybernetics, Bogdan Khmelnitsky Melitopol state pedagogical university, Melitopol, Ukraine

Viacheslav Osadchyi, born in 1975, received a Candidate of Pedagogical Sciences (PhD in Education) from the Vinnytsia State Pedagogical University named after Mykhailo Kotsiubynsky, Ukraine, in 2006, and a Doctor of Pedagogical Sciences from the Vinnytsia State Pedagogical University named after Mykhailo Kotsiubynsky, Ukraine, in 2013.

Since 1999, he has been working in the field of information technology and vocational education at the Bogdan Khmelnitsky Melitopol State Pedagogical University. Now - Head of the Department of Computer Science.

His research interests include: computer science, information networks, ICT, programming, software development, information systems, data science. He has published a number of papers in international journals.

He is a member of editorial boards of "Ukrainian Journal of Educational Studies and Information Technology" (Ukraine), "International Conference on Higher Education Advances" (Spain), "Transactions of Kremenchuk Mykhailo Ostrohradskyi National University" (Ukraine), "Information Technologies and Learning Tools" (Ukraine), "Scientific papers of Berdyansk State Pedagogical University Series: Pedagogical sciences" (Ukraine).

WWW: http://osadchyi.mdpu.org.ua/

E-mail: poliform55@gmail.com

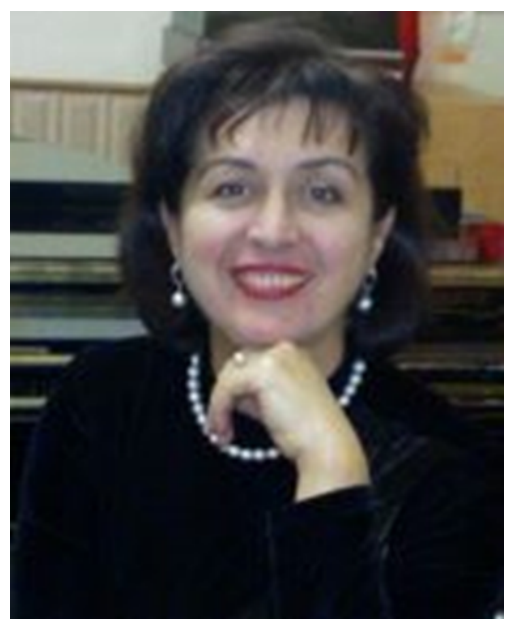

Dr. Nataliia Ovcharenko, Professor of Music Art and Pedagogy, Department of Music Education, Vocal and Choir Conducting, Kryvyi Rih State Pedadogical University, Kryvyi Rih, Ukraine

Nataliia Ovcharenko, born in 1965, received a Candidate of Pedagogical Sciences degree (Dr. Phil. (Music Art)) from H. S. Skovoroda Kharkiv National Pedagogical University, Ukraine, in 1994, and a Doctor of Pedagogical Sciences degree (Dr. habil.) from Borys Grinchenko Kyiv University, Ukraine, in 2016. Since 1990, she has been working in the field of music art and pedagogics at Kryvyi Rih State Pedagogical University. Her research interests include vocal performance, pedagogics and inclusive music education.

She has published the papers in international journals and monographs in Ukraine, is a member of National All-Ukrainian Musical Association.

WWW: https://kdpu.edu.ua/personal/naovcharenko.html E-mail: shvager77@gmail.com

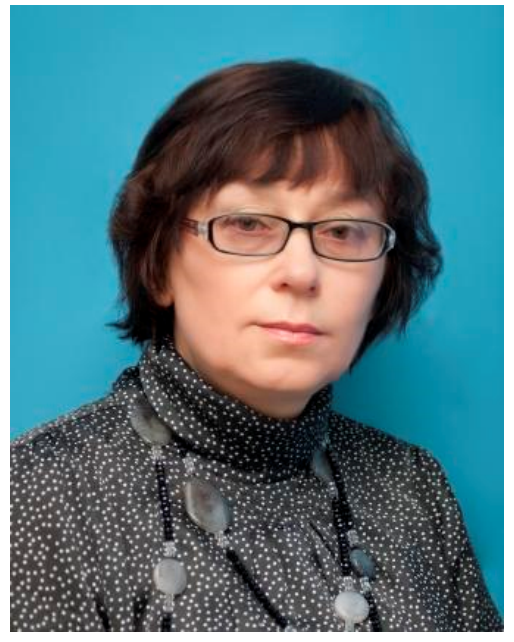

Dr. Liubov Panchenko, Professor at the Department of Sociology, National Technical University of Ukraine "Igor Sikorsky Kyiv Polytechnic Institute", Kyiv, Ukraine

Liubov Panchenko was awarded a Candidate of Pedagogical Sciences degree (Dr. phil.) from H. S. Skovoroda Kharkiv National Pedagogical University, Kharkiv, Ukraine, in 1995, and a Doctor of Pedagogical Sciences degree (Dr. habil.) from the Luhansk Taras Shevchenko National University, in 2012. Since 1993, she has been working in the field of information and communication technology in education. Since 2016 she has been a Professor at the Department of Sociology, National Technical University of Ukraine "Igor Sikorsky Kyiv Polytechnic Institute". Her research interests include information and communication technology in education, university's educational environment, MOOCs, data analysis and multivariate methods in scientific research, digital storytelling, adult education. She has published a number of papers and text books ("Computer data analysis", "Data analysis practicum") and is an editorial board member of the Ukrainian journals "Information Technologies and Learning Tools" (associated editor), "e-Environment of Modern University", and "Humanization of the educational process". 


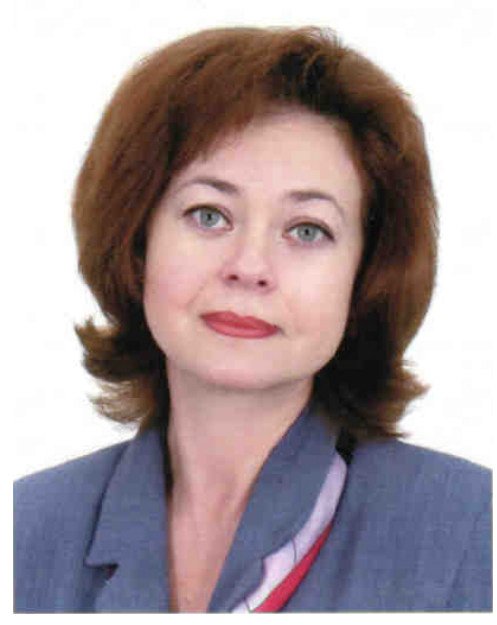

WWW: http://www.sociology.kpi.ua/en/faculty-2

E-mail: lubov.felixovna@gmail.com

Dr. Oksana Pershukova, Professor of Aviation English Department, National Aviation University, Kyiv, Ukraine

Oksana Pershukova received a Candidate of Pedagogical Sciences degree (Dr. phil.) from the Institute of Pedagogy of the NAPS of Ukraine (Kyiv) in 2002, and a Doctor of Pedagogical Sciences degree (Dr. habil.) from the Institute of Pedagogical Education and Education of Adults of the NAPS of Ukraine (Kyiv), in 2016. Since 1995, she has been working in the field of comparative education in the Institute of Pedagogy, Kyiv. Since 2017 she works at the National Aviation University, Kyiv, at the position of a Professor of Aviation English Department. Her research interests are related to improving the quality of bilingual and multilingual education, developing and preserving multilingualism in the context of the educational space of European countries and the US. She has been analyzing the opportunities and finding ways to apply positive experiences in these fields in Ukraine. The range of her scientific interests also includes features of mastering a foreign language at the university level (especially ESP), as well as peculiarities of forming students' autonomy and finding the ways to increase students' motivation for foreign languages learning.

\section{E-mail: pershoks@gmail.com}

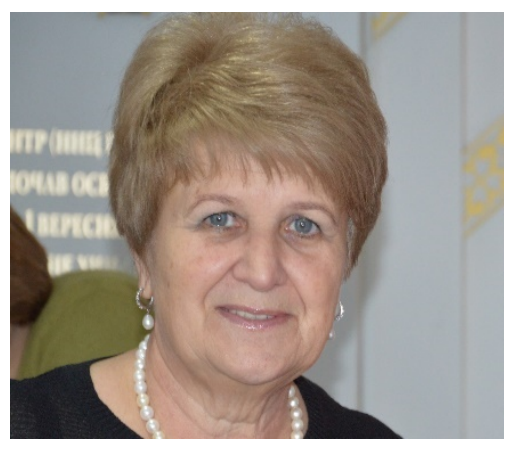

Dr. Larysa Petrenko, Senior Researcher, Professor of the Department of Vocational and Higher Education, University of Educational Management, Kyiv, Ukraine.

Larysa Petrenko, born in 1951, received a Candidate of Pedagogical Sciences degree (Ph.D.) in 2006 from the Institute of Pedagogy of the National Academy of Educational Sciences of Ukraine, and a Doctor of Pedagogical Sciences from the Institute of Vocational Education of NAESU in 2014. Since 2019, she has been a professor in the field of vocational and higher education at the University of Educational Management. Her research interests include the informational culture, information and analytical competence of pedagogical, scientificpedagogical staff and heads of educational institutions of various types. She has published a number of articles in domestic and foreign collections of scientific papers and monographs were published. She is also a member of the editorial board of researcher's digest "Scientific Herald of the Institute of Vocational Education and Training of NAESU. Professional Pedagogy".

WWW: http://umo.edu.ua/institutes/cippo/struktura/kafedra-upop/sklad E-mail: laravipmail@gmail.com

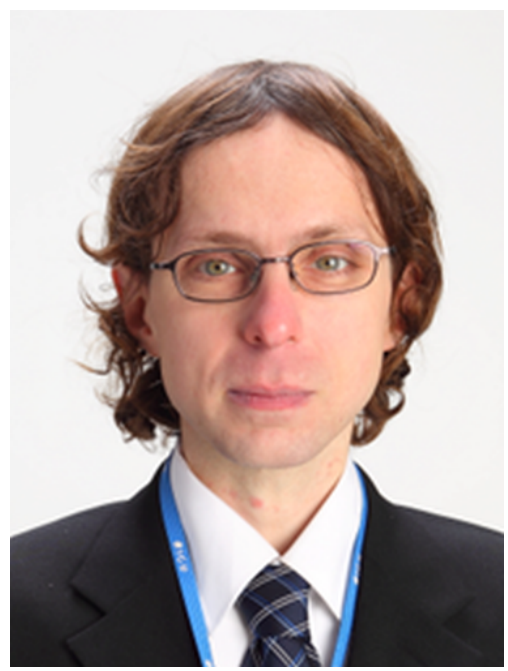

Dr. Lukáš Pichl, Senior Associate Professor of Information Science, Department of Natural Sciences, International Christian University, Mitaka, Tokyo, Japan

Lukáš Pichl, born in 1974, received his PhD from the Graduate University of Advanced Studies in 2000. Since 2001 he taught computer science in the University of Aizu, before joining the International Christian University in 2005. His current field of specialization is time series analysis and machine learning algorithms for the analysis of economic data including cryptocurrencies. Dr. Pichl has published a number of papers in international journals; he is a member of ACM and IEEE Computer Society, and currently serves as an associate editor of the Journal of Economic Interaction and Coordination (Springer).

E-mail: lukas@icu.ac.jp 

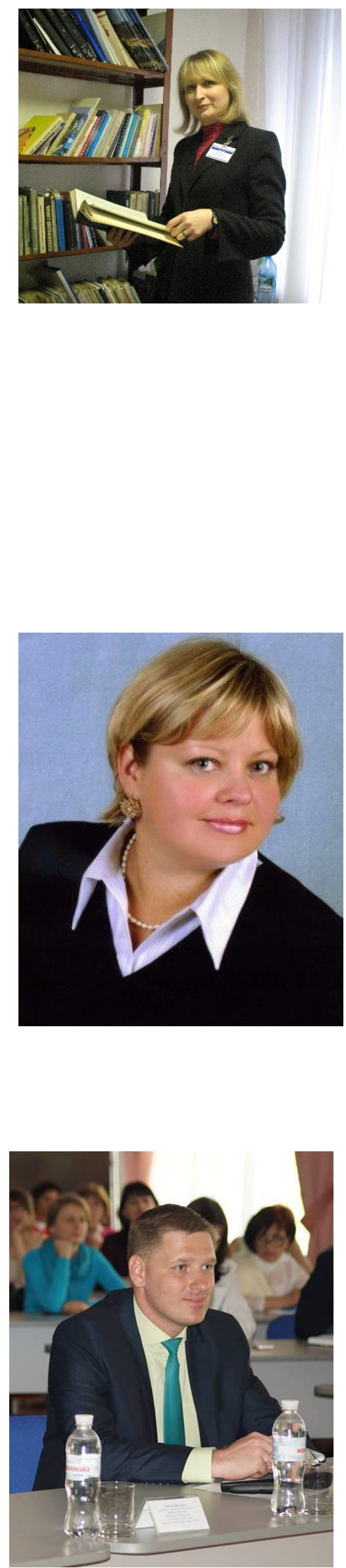

Dr. Olga P. Pinchuk, Deputy Director for Scientific Experimental Work, Leading Researcher, PhD (in Pedagogics), Senior Researcher in the field of information and communication technologies in education. Education: M.P. Drahomanov Kyiv State Pedagogical Institute in specialties of Mathematics, Computer Science and Computer Engineering teacher.

Currently the experience in teaching is 25 years. Since 2005 I work in the Institute of Information Technologies and Learning Tools of the NAES of Ukraine. I worked on the implementation of the tasks of the scientific research works "Scientific and methodological foundations use of computer oriented tools in teaching natural and mathematical subjects in profile School", "Scientific and methodological principles of organization of distance learning environment in secondary schools" , "Methodology of design network resource centers of distance education of secondary schools", "Formation of information and educational environment for learning high school students through technology electronic social networks" (Head of Scientific Research). I have more than 80 published scientific works, the author of collective monographs, manuals. I also obtain the post of co-editors-in-chief of "Information Technologies and Learning Tools", a bimonthly peer-reviewed e-journal in educational sphere, publishing full-text articles online with immediate open-access.

WWW: http://iitlt.gov.ua/

E-mail: opinchuk@iitlt.gov.ua

Dr. Nataliia O. Ponomarova, Doctor of Pedagogical Sciences, Professor of Department of Informatics, H. S. Skovoroda Kharkiv National Pedagogical University, Kharkiv, Ukraine

Nataliia O. Ponomarova, born in 1972, received a Candidate of Pedagogical Sciences degree (Dr. phil.) from the H. S. Skovoroda Kharkiv National Pedagogical University, in 1998, and a Doctor of Pedagogical Sciences degree (Dr. habil.) from the H. S. Skovoroda Kharkiv National Pedagogical University, in 2018. Since 2005, she has been working in the field of preparation of teachers of informatics at H. S. Skovoroda Kharkiv National Pedagogical University, where she is currently Dean of Department of Physics and Mathematics. Her research interests include innovative pedagogical technologies; use of information and communication technologies in education; theoretical and methodological foundations of professional training of future teachers of informatics; career guidance of students. She has published a number of papers in international journals and volumes in book series.

WWW: http://hnpu.edu.ua/uk/ponomarova-nataliya-oleksandrivna E-mail: ponomna@gmail.com

Dr. Volodymyr Proshkin, Professor of Department of Computer Science and Math, Borys Grinchenko Kyiv University, Kyiv, Ukraine

Expert of the National Agency for Higher Education Quality Assurance. Deputy Chairman of the Specialized Academic Council (Borys Grinchenko Kyiv University), member of the specialized Academic Council (Donbass State Pedagogical University). Executor of the international project "High school teacher competence in change" with the assistance of the Visegrad Fund and the Ministry of Foreign Affairs of the Netherlands.

Author of 10 articles in journals included in the databases Scopus, WoS. Member of editorial boards of journals: "Open educational e-environment of modern University", "Cybersecurity: Education, Science, Technique" (Borys Grinchenko Kyiv University), "Transactions of Kremenchuk Mykhailo Ostrohradskyi National University".

WWW: http://fitu.kubg.edu.ua/pro-fakultet/kafedry

E-mail: v.proshkin@kubg.edu.ua 


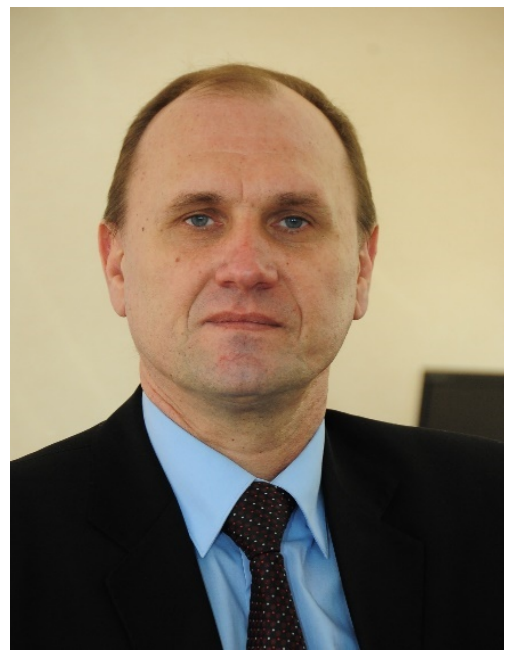

Dr. Oleg Pursky, Professor of Computer Science and Information Systems, Head of Department of Computer Science and Information Systems, Kyiv National University of Trade and Economics, Kyiv, Ukraine

Oleg Pursky, born in 1967, received a Candidate of Sciences in Physics and Mathematics degree (Dr. phil.) from the Institute for Low Temperature Physics and Engineering of the National Academy of Sciences of Ukraine, in 2001, and a Doctor of Sciences in Physics and Mathematics degree (Dr. habil.) from the Taras Shevchenko National University of Kyiv, Ukraine, in 2010. His research interests include informational systems development, computer simulation and modeling of socio-economic systems. He has published a number of papers in international journals, monographs and volumes in book series, is a member of editorial board of International Journal of Economic Theory and Application, reviewer of scientific journals International Journal of Modern Physics (B) and Heat Transfer and certified Data Science \& Machine Learning specialist. He is a member of Scientific Council section of Ukrainian Ministry of Education and Science on the specialty "Informatics and Cybernetics". Currently, he is working as a Head of Department of Computer Science and Information Systems, Kyiv National University of Trade and Economics.

WWW: https://knute.edu.ua/blog/read/?pid=12695\&uk E-mail: Pursky_O@ukr.net
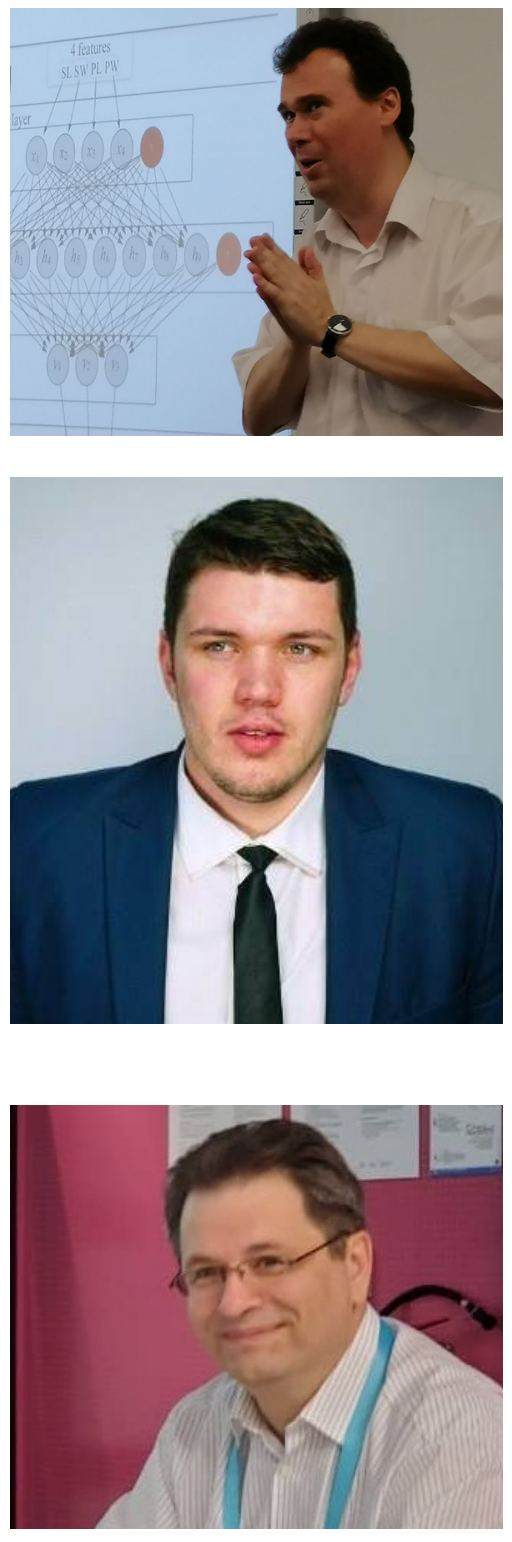

Dr. Serhiy Semerikov, Professor of Computer Science and Educational technology, Kryvyi Rih State Pedagogical University, Ukraine

Serhiy Semerikov is professor of Department of Computer Science and Applied Mathematics at Kryvyi Rih State Pedagogical University. He got both PhD and DSc in education (informatics) from the National Pedagogical Dragomanov University in 2001 and 2009, respectively. The main directions of Dr. Semerikov' research is methods of learning and educational technology.

WWW: https://kdpu.edu.ua/semerikov/

E-mail: semerikov@gmail.com

Dr. Yevhenii Shapovalov, a researcher at Junior Academy of Science of Ukraine, Chief Specialist at Ministry of Digital Transformation of Ukraine

Yevhenii Shapovalov was born in 1992. He defended Ph.D. in 2019 in the field of Biotechnology at the National University of life and environmental sciences of Ukraine. Since 2014 worked in the National Academy of Science of Ukraine where he provided chemical laboratory, work in science in the field of computer sciences. Science 2020 starts working at the Ministry of Digital Transformation of Ukraine. He was a participant of 3 international Jean Monnet projects related to implementing European standards in Educational programs on Environmental Sciences and Sustainable development.

WWW: http://www.nas.gov.ua/UA/PersonalSite/Pages/default.aspx?PersonID= 0000026333

E-mail:sjb@man.gov.ua

Dr. Yaroslav Shramko, Professor of Logic and Philosophy, Department of Philosophy, Kryvyi Rih State Pedagogical University, Kryvyi Rih, Ukraine

Yaroslav Shramko, born in 1963, received a Candidate of Philosophical Sciences degree (Dr. phil.) from the Lomonosov Moscow State University, USSR, in 1990, and a Doctor of Philosophical Sciences degree (Dr. habil.) from the Institute of Philosophy of the National Academy of Sciences of Ukraine, in 1998. Since 1990, he has been working in the field of logic and analytic philosophy at the Kryvyi Rih State Pedagogical University, where he is currently rector. His research interests include non-classical logic and analytic philosophy. He has published a number of papers in international journals and volumes in book series, is a 

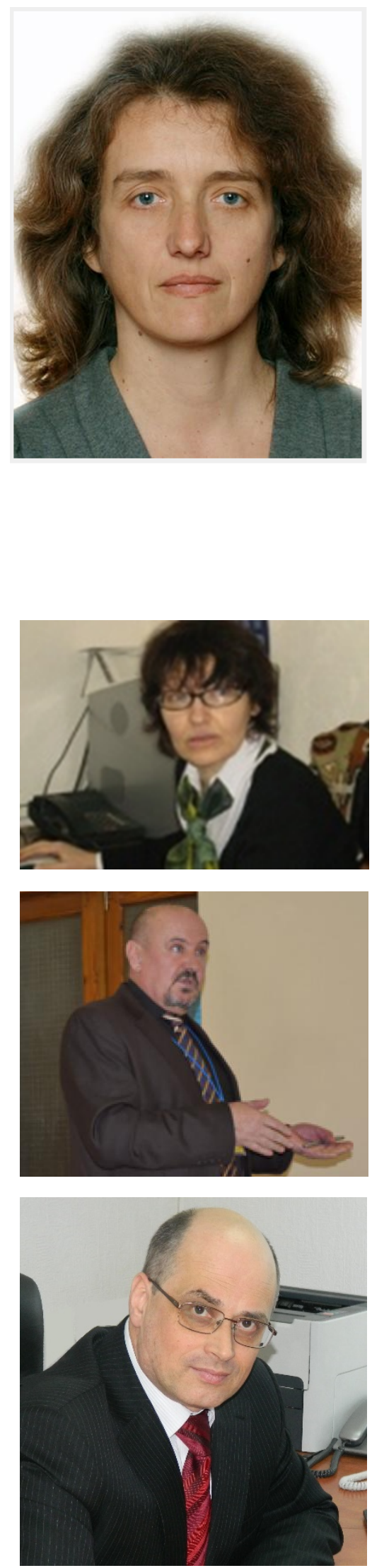

member of editorial boards of Studia Logica, European Journal of Mathematics, Logic and Logical Philosophy.

WWW: https://kdpu.edu.ua/shramko/yse.htm

E-mail: shramko@rocketmail.com

Dr. Mariya Shyshkina, Head of Department of Cloud-based Systems for Education Informatization of the Institute of Information Technologies and Learning Tools of the National Academy of Educational Sciences of Ukraine, Kyiv, Ukraine

Mariya Shyshkina, born in 1969, received a Candidate of Philosophical Sciences degree (PhD, Philosophy) from the Institute of Philosophy of the National Academy of Sciences of Ukraine, Kyiv, Ukraine, 1999, and a Doctor of Educational Sciences degree (Dr. habil.) from the Institute of Information Technologies and Learning Tools of the National Academy of Educational Sciences of Ukraine, 2016, Kyiv, Ukraine. Since 1999, she has been working in the field of information and communication technologies for education at the Institute of Information Technologies and Learning Tools of NAES of Ukraine where she is currently a chief of a department. Her research interests include philosophy of education, ICT for learning and research. She has published a number of papers in international journals and volumes in book series, is a member of editorial board of Information Technologies and Learning Tools Journal.

WWW: http://iitlt.gov.ua/eng/structure/departments/cloud/detail.php?ID=269 E-mail: shyshkina@iitlt.gov.ua

Dr. Oleksandra Sokolyuk, Institute of Information Technologies and Learning Tools of the NAES of Ukraine, Ukraine

WWW: http://ittlt.gov.ua/eng/structure/departments/technology/detail.php?ID=2 74

Prof. Vladimir Soloviev, Kryvyi Rih State Pedagogical University, Ukraine

WWW: https://kdpu.edu.ua/personal/vmsoloviov.html

Dr. Oleg Spirin, Doctor of Pedagogy, Full Professor, Corresponding Member of the National Academy of Pedagogical Science of Ukraine, Vice Rector for Research and Digitalization of the University of Educational Management, Kyiv, Ukraine

Oleg Spirin, born in 1965, 1989 - graduated from Zhytomyr Ivan Franko State University, Ukraine, majoring in Mathematics and Physics. Scientific degree: Ph.D (2002), Thesis "Differentiated approach to the Study of the Foundations of Artificial Intelligence in Computer Science Course Physics and Mathematics in Higher Educational Institutions"; Doctor of Pedagogical Sciences (2009), Thesis "Theoretical and Methodological Basis of Credit-modular System of Future Teachers of Informatics Training". Academic status: Associate Professor of Computer Science (2004). Professor of the specialty 13.00.10 - Information 

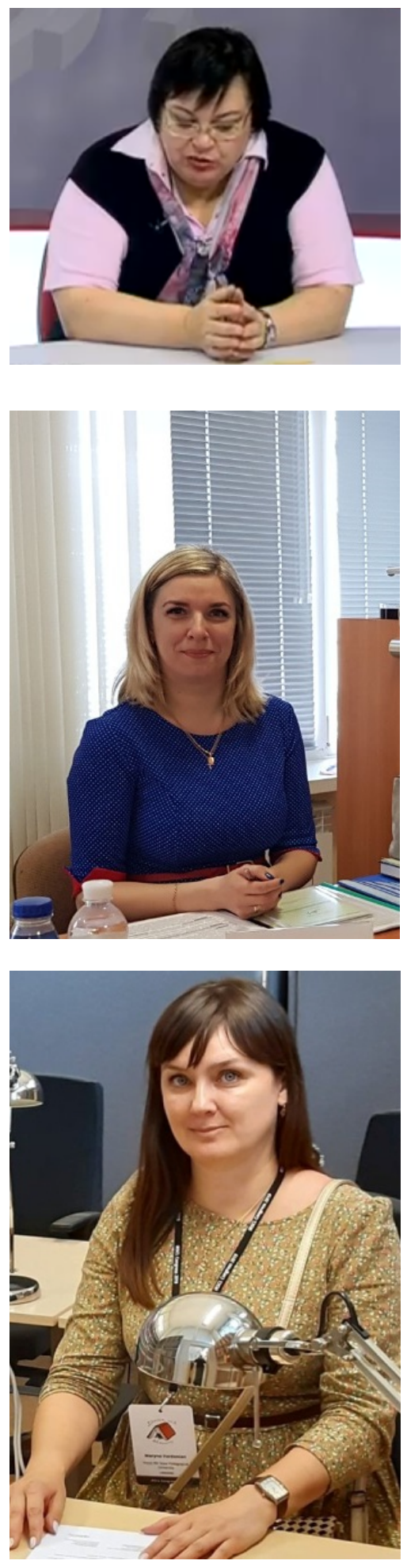

Technologies in Education (2013). Prof. Spirin is an expert in the informatization of education and science and information training of students. He has published a number of papers in international journals and volumes in book series, is Deputy Editor-in-Chief of Electronic scientific edition "Information Technologies and Learning Tools", member of the Editorial Boards of the specialized journals "Information Technologies in Education", "Computer in School and Family".

WWW: http://umo.edu.ua/en/university/leadership/spirin-olegh-mikhajlovich E-mail: oleg.spirin@gmail.com

Dr. Iryna Trubavina - Doctor of Pedagogical sciences, professor of Department of General pedagogics and pedagogic of High education, H. S. Skovoroda Kharkiv national pedagogical university, consultant of the La Strada - Ukraina (2000-2015), scientific consultant of the State Social services for families, children and youth (2000-2006).

Field of scientific interest: social pedagogics, social work, education, family, pedagogics skills. She is Editor of the journal "Social Work in Ukraine: Theory and Practice".

WWW: http://hnpu.edu.ua/uk/trubavina-iryna-mykolayivna E-mail: trubavina@gmail.com

Dr. Tetiana Vakaliuk, professor of the department of Software Engineering, Zhytomyr Polytechnic State University, Zhytomyr, Ukraine.

Tetiana Vakaliuk, born in 1983, received a Candidate of Pedagogical Sciences degree from the National Pedagogical Dragomanov University, Ukraine, in 2013, and a Doctor of Pedagogical Sciences degree from the Institute of Information Technologies and Learning Tools of the National Academy of Sciences of Ukraine, in 2019. Since 2019, she has been working in the field of information technologies at the Zhytomyr Polytechnic State University. Her research interests include information technologies, ICT in Education, Cloud technologies. She has published a number of papers in international journals, is a member of editorial boards of Information Technologies and Learning Tools, Zhytomyr Ivan Franko State University Journal: Pedagogical Sciences, Collection of Scientific Papers of Uman State Pedagogical University.

WWW: https://sites.google.com/view/neota

E-mail: tetianavakaliuk@gmail.com

Dr. Maryna Vardanian, Full Professor of Children's Literature and Comparative Literature, Faculty of Foreign Languages, Kryvyi Rih State Pedagogical University, Kryvyi Rih, Ukraine

Maryna Vardanian, born in 1979, received a Candidate of Philological Sciences degree (PhD in Philology) from The Volodymyr Vynnychenko State Pedagogical University of Kirovograd (Kropyvnytskyi, Ukraine), in 2010, and a Doctor of Philological Sciences degree (Dr. habil.) from The Bohdan Khmelnytsky National University of Cherkasy, Ukraine, in 2019. Since 2012, she has been working in the field of children's literature and comparative literature at the Kryvyi Rih State Pedagogical University, where she is currently Dean of Faculty of Foreign Languages. Her research interests include literary imagology, translating studies and literature written by Ukrainian Diaspora. She has published a number of papers in journals, is a member of International Research Society for Children's Literature, and editorial board of Literatures of the World: Poetics, Mentality and Spirituality.

WWW: https://kdpu.edu.ua/personal/pm_rectora.html E-mail: maryna.vardanian@gmail.com 

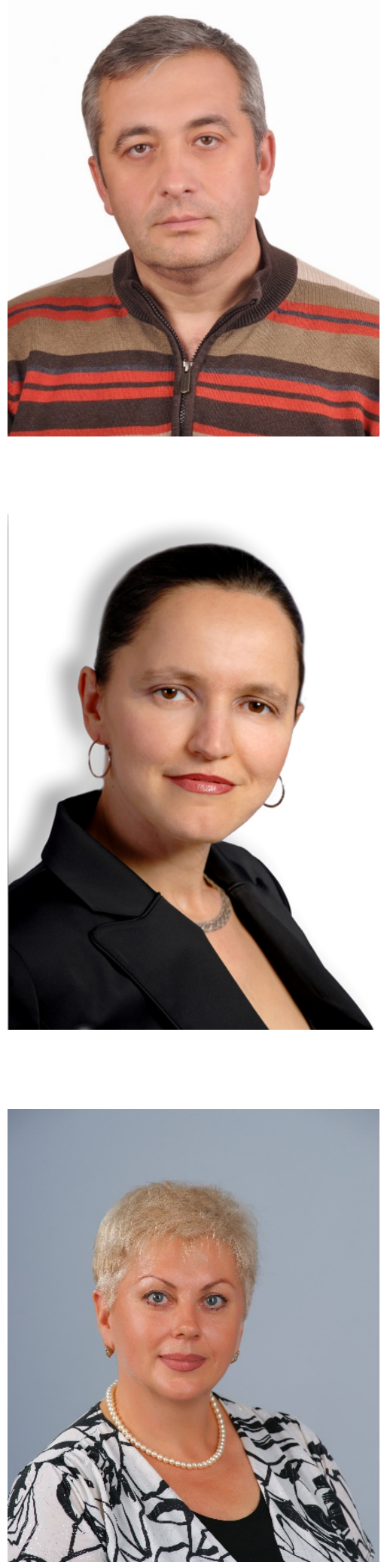

Dr. Vladyslav Velychko, Full Professor of the Chair of Teaching Methods of Mathematics and Teaching Methods of Computer Sciences, State Higher Educational Institution "Donbas State Pedagogical University", Sloviansk, Ukraine

Vladyslav Velychko, born in 1973, received a Candidate of Physical and Mathematical Sciences (PhD.) from the Taras Shevchenko National University of Kyiv, Ukraine, in 2007. Since 1994 he has been working in the field of algebra and number theory and in the field of information and communication technologies in education at Donbas State Pedagogical University. His research interests include quasi-ideal of semigroups, free software in education, open electronic educational resources. He has published a number of papers in international journals, and is a member of the editorial boards of the Collection of Scientific Papers of the Faculty of Physics and Mathematics of Donbas State Pedagogical University and the electronic journal of E-Learning TeXnology.

\section{E-mail: vladislav.velichko@gmail.com}

Dr. Kateryna Vlasenko, Professor of Mathematics, Head of the Mathematics and Modeling Department, Donbas State Engineering Academy, Kramatorsk, Ukraine

Kateryna Vlasenko, born in 1966, received a Candidate of Pedagogical Sciences degree $(\mathrm{PhD})$ from the National Pedagogical Dragomanov University, Ukraine, in 2004, and a Doctor of Pedagogical Sciences degree (D.Sc. in Educational Science) from the Bohdan Khmelnytsky National University of Cherkasy, in 2011. Since 2008, she has been working in the field of mathematical and pedagogical modeling at Donbas State Engineering Academy, where she is currently head of the Mathematics and Modeling Department. Her research interests include the issues of mathematics education. She has published a number of papers in international journals and volumes in book series, is a member of editorial boards of Innovative Solutions in Modern Science, Topical Issues of Natural and Mathematical Education Sumy State Pedagogical University named after A. Makarenko.

WWW: http://formathematics.com/

E-mail: vlasenkokv@ukr.net

Dr. Nataliia Volkova, Doctor of Pedagogy, Professor, Head of the Department of Pedagogy and Psychology, Alfred Nobel University, Dnipro, Ukraine

Nataliia Volkova born in 1959. Year 2006 - defended Doctoral Dissertation on "Theoretical and Methodological Principles of Training Future Teachers for Vocational and Pedagogic Communication", specialization 13.00.04 - "Theory and Methodology of Professional Education". Year 2008 - awarded the title of "Professor of the Department of Pedagogy". Leading expert in pedagogy of higher education in Ukraine. Author of more than 160 printed works, three monographs, two textbooks with a stamp of the Ministry of Education and Science of Ukraine, three study guides with a stamp of the Ministry of Education and Science of Ukraine, 12 educational and practical study guides, articles in leading Ukrainian and foreign journals.

WWW: https://duan.edu.ua/university-ukr/kafedry/15-pages/332-kafedrapedahohiky-ta-psykholohii.html

E-mail: npvolkova@yahoo.com,npvolkova@duan.edu.ua 


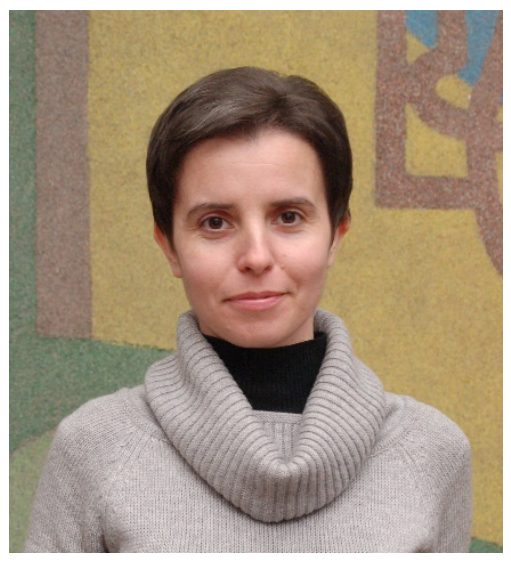

Dr. Yuliia Yechkalo, Associate professor, Department of Physics, Kryvyi Rih National University

Yuliia Yechkalo, born in 1981, received a Candidate of Pedagogical Sciences degree from the Kirovograd State Vladimira Vinnichenka Pedagogical University, Ukraine, in 2013. Since 2005, she has been working at the National Metallurgical Academy of Ukraine. She has been working at the Kryvyi Rih National University since 2012. Her research interests include theory and methods of education (physics) and information and communication technologies in education.

E-mail: uliaechk@gmail.com

\section{Conclusion}

The vision of the ICHTML 2020 is to create a leading interdisciplinary platform for researchers, practitioners and educators, to present and discuss the most recent innovations, trends, and concerns as well as practical challenges encountered and solutions adopted in the fields of learning.

The conference is a successfully performing forum to transferring and discussing research result among the academics, students, teachers, government, private sector or industries. Participants and presenters from several countries such as Israel, Italy, Lithuania, Moldova, Netherlands, Poland, Romania, Russia, Sweden and Ukraine have attended the conference to share their significant contribution in research related to the History, Theory and Methodology of Learning.

We are thankful to all the authors who submitted papers and the delegates for their participation and their interest in ICHTML as a platform to share their ideas and innovation. Also, we are also thankful to all the program committee members for providing continuous guidance and efforts taken by peer reviewers contributed to improve the quality of papers provided constructive critical comments, improvements and corrections to the authors are gratefully appreciated for their contribution to the success of the conference. Moreover, we would like to thank the developers and other professional staff of EasyChair, who made it possible for us to use the resources of this excellent and comprehensive conference management system, from the call of papers and inviting reviewers, to handling paper submissions, communicating with the authors, and creating the conference proceedings.

We are looking forward to excellent presentations and fruitful discussions, which will broaden our professional horizons. We hope all participants enjoy this conference and meet again in more friendly, hilarious, and happiness of further ICHTML 2021.

\section{References}

1. V. Richardson, 'Inducing panic': Media under fire for driving coronavirus hype to epidemic levels (The Washington Times, New York, 2020), https://www.washingtontimes.com/news/2020/mar/1 1/media-fueling-coronavirus-panic-under-fire/. Accessed 16 Mar 2020.

2. Cabinet of Ministers of Ukraine, Regulation No. 211 dated March 11, 2020, published on the governmental portal (2020), https://www.kmu.gov.ua/npas/pro-zapobigannyaposhim110320rennyu-na-teritoriyi-ukrayinikoronavirusu-covid-19. Accessed 16 Mar 2020

3. J. Conduitt, Draft account of Newton's life at Cambridge

(2004), http://www.newtonproject.ox.ac.uk/view/texts/norm alized/THEM00167. Accessed 16 Mar 2020

4. G. Brockell, During a pandemic, Isaac Newton had to work from home, too. He used the time wisely (The Washington Post, 2020), https://www.washingtonpost.com/history/2020/03/1 2/during-pandemic-isaac-newton-had-work-hometoo-he-used-time-wisely. Accessed 16 Mar 2020

5. Coursera Coronavirus Response Initiative $\mid$ Coursera for Campus (2020), https://www.coursera.org/coronavirus. Accessed 16 Mar 2020

6. Contingency Planning For Moving Courses Online | UMass Amherst Response to the Coronavirus (COVID-19) https://www.umass.edu/coronavirus/news/contingen cy-planning-moving-courses-online. Accessed 16 Mar 2020

7. Kryvyi Rih State Pedagogical University (2020), https://kdpu.edu.ua/en/. Accessed 16 Mar 2020 